School of Finance

University of St.Gallen

THE LONG-TERM PERFORMANCE OF IPOS, REVISITED

DANIEL HOECHLE

LARISSA M. KARTHAUS

MARKUS SCHMID

WORKING PAPERS ON FINANCE NO. 2017/06

SWISS INSTITUTE OF BANKING AND FINANCE (S/BF - HSG)

MARCH 2017 


\title{
The Long-Term Performance of IPOs, Revisited*
}

\author{
Daniel Hoechle \\ University of Applied Sciences and Arts Northwestern Switzerland \\ Larissa M. Karthaus ${ }^{\#}$ \\ University of St. Gallen \\ Markus Schmid \\ University of St. Gallen
}

March 2017

\begin{abstract}
The literature on IPO long-term performance generally focuses on three- to five-year post-issue time horizons. Research published in the 2000s shows that the apparent underperformance of IPOs documented in the 1990s disappears when the different risk exposures between IPO and mature firms are accounted for by using a Carhart (1997) factor model. In this paper, we show that a sample of 7,487 U.S. IPOs between 1975 and 2014 continues to significantly underperform mature firms in terms of Carhart-alphas over two years, with underperformance peaking one year after going public. We apply a regression-based portfolio sorts approach (RPS), which allows to decompose the Carhart-alpha into firm-specific characteristics, to explain one-year IPO underperformance using a multitude of market and firm characteristics in a statistically robust setting. In fact, our RPS-model that augments the Carhart factors by a set of firm characteristics related to investments, internationality, liquidity, and leverage can explain IPO underperformance. We find similar results when using the Fama-French three-factor model or an augmented version of the Carhart model. We challenge our RPS-model by applying it to the most severely underperforming sub-samples in terms of firm size, time period, venture capital involvement, and IPO underpricing, and find it to explain IPO underperformance across all sub-samples.
\end{abstract}

Keywords: IPO underperformance, long-term performance evaluation, time horizon, firm characteristics JEL classification: G14, G24, G32

\footnotetext{
* We are grateful to Yakov Amihud, Matthias Grueninger, Jason Karceski, Christian Kleiber, Ernst Maug, David Oesch, Urs Peyer, David Rey, Silvio Vismara, Ingo Walter, Evert Wipplinger, Heinz Zimmermann, and seminar participants at the University of Basel, University of St. Gallen, University of Mannheim, the EFMA IPO Symposium at Oxford University, and the Annual Conference of the Swiss Society for Financial Market Research in Zurich for helpful comments and discussions.

\# Corresponding author: Tel.: +41-71-224-7007; E-mail: larissa.karthaus@unisg.ch. Address: Swiss Institute of Banking and Finance, University of St. Gallen, Unterer Graben 21, CH-9000 St. Gallen, Switzerland.
} 


\section{Introduction}

In a seminal paper, Ritter (1991) documents a significant underperformance of IPO firms over the first three years after going public. Loughran and Ritter $(1995,2000)$ find a strong underperformance of IPOs over a five-year period following the issue date. Brav and Gompers (1997), Brav, Geczy, and, Gompers (2000), and Gompers and Lerner (2003) show that IPO firms are strongly tilted towards small and high-growth companies which has been the worst-performing investment style over the last several decades. Consistently, these studies show that the apparent underperformance of IPO firms disappears when controlling for size and the book-to-market ratio, concluding that IPO firms do not perform worse than similar non-issuing companies.

In this paper, we show that while a Carhart (1997) four-factor model explains IPO underperformance over three- to five-year post-issue periods, IPO firms continue to underperform over the first two years after going public - even when differences in size, book-to-market, and momentum are accounted for. More generally, we show that IPO underperformance is highly dependent on the time horizon over which post-IPO performance is measured. In a sample of 7,487 U.S. firms going public from 1975 to 2014, we find underperformance to peak at a risk-adjusted $-2.375 \%$ per quarter exactly one year after going public. Then underperformance gradually declines and becomes insignificant beyond two years after going public. Hence, while prior research analyzing three- and five-year time horizons apparently solved the IPO underperformance puzzle by using a Carhart (1997) four-factor model, we reopen the quest for a solution to this puzzle by showing that there is a statistically significant and economically meaningful underperformance of IPO firms over time horizons of up to two years even when the usual risk factors are accounted for. ${ }^{1}$

We then employ a new regression-based version of the traditional portfolio sorts approach, proposed by Hoechle, Schmid, and Zimmermann (2016), to explore potential reasons for the economically and statistically significant one-year IPO underperformance. This "regression-based portfolio sorts" (or

\footnotetext{
${ }^{1}$ In the ten-year period 2007-2016, the top four academic finance journals (JF, RFS, JFE, and JFQA) published a total of 114 papers on IPOs, whereof 24 articles analyze the long-term performance of IPOs. Only two of these papers use factor models to evaluate long-term performance (Lyandres, Sun, and Zhang, 2008; Bessembinder and Zhang, 2013). Both of these papers focus on a five-year post-issue period. 
RPS) model relies on estimating a pooled linear regression with cross-sectional correlation consistent Driscoll and Kraay (1998) standard errors. The model specification is such that the individual firms' quarterly excess returns are regressed on the market factors (e.g., the four Carhart factors), a set of individual firm characteristics, and all interaction terms between the market factors and the firm characteristics. The RPS-model allows us to decompose the (Carhart-)alpha into firm specific components and thereby remedies the major drawback of the widely used portfolio sorts approach by allowing for the inclusion of continuous and multivariate firm characteristics in the analysis.

The traditional portfolio sorts approach (Jaffe, 1974; Mandelker, 1974) first calculates period-byperiod mean excess returns of portfolios of event firms (e.g., IPO firms) and then regresses these average returns on a set of market factors (e.g., the four Carhart factors) to identify the risk-adjusted performance of the respective portfolio. As the construction of portfolios based on various different variables, and in particular based on continuous variables, in the first step of the portfolio sorts approach makes the analysis unwieldy and the results difficult to interpret, the analysis is usually carried out onedimensionally (e.g., by comparing venture-backed to nonventure-backed IPOs). The RPS-model preserves the major advantage of the portfolio sorts approach, which is to ensure valid statistical inference in the presence of cross-sectional (and temporal) dependence. ${ }^{2}$ This latter characteristic distinguishes the portfolio sorts approach, and by extension the RPS-model, from the widely used buy-and-hold abnormal return (BHAR) approach (e.g., see Barber and Lyon, 1997) which is not robust to crosssectional dependence (Fama, 1998). ${ }^{3}$ In contrast to both the traditional portfolio sorts approach and the BHAR approach, the RPS-model allows us to simultaneously control for various explanations for the apparent IPO underperformance which have been put forward in previous research in a statistically robust setting. Recent applications of the RPS-model include Doskeland and Hvide (2011), Jenkinson, Jones, and Martinez (2016), and Dahlquist, Martinez, and Söderlind (forthcoming).

\footnotetext{
${ }^{2}$ Hoechle, Schmid, and Zimmermann (2016) show both theoretically and empirically, that their regression-based technique is capable to perfectly replicate the results of the traditional calendar time portfolio approach in a single step rather than in two. Consequently, the RPS-model has the same statistical properties as the traditional calendar time portfolio approach.

3 The BHAR approach is based on calculating the average difference between buy-and-hold returns of IPO firms and respective buy-and-hold returns of matched control firms.
} 
To identify relevant firm (and market) characteristics that may proxy for pricing-relevant differences between IPO and mature firms, and thus help in explaining IPO underperformance, we rely on previous research. Loughran and Ritter (1995) document that firms going public during times of high issuing activity, so called "hot" IPO issue periods, have the lowest long-term returns. Lyandres, Sun, and Zhang (2008) test an investment-based explanation for IPO underperformance. Consistent with theoretical models by Cochrane (1991) and Carlson, Fisher, and Giammarino (2004), that suggest a negative relation between investments and expected returns, they show that IPO firms invest more than mature firms and thus achieve lower returns in the long run. Brau, Couch, and Sutton (2012) attribute long-term IPO underperformance to an increased acquisition activity of IPO firms. They show that only IPO firms that acquire another company during the first year after going public underperform in the long run. Eckbo and Norli (2005) identify stock turnover as a driver of IPO underperformance. They argue that the higher liquidity of IPO stocks reduces systematic risk exposure and thus explains lower expected returns. Furthermore, they suggest a "turbo-charging" effect of leverage. Higher leverage increases factor loadings in a multi-factor model. Consequently, Eckbo and Norli (2005) argue that the lower leverage ratios of IPO firms decrease their systematic risk exposure resulting in lower expected equity returns. Mauer, Wang, Wang, and Zhang (2015) provide evidence that globally diversified IPO firms perform better than purely domestic IPO firms over three- and five-year periods after going public. Bessembinder and Zhang (2013) augment the BHAR method to account for volatility, illiquidity, and investments besides the four Carhart factors. Controlling for these characteristics, they find that the performance of IPO stocks does not significantly differ from the performance of non-IPO stocks over a five-year postissue period.

Our RPS-model estimations reveal that neither the issue period nor differences in investments, international business activity, or leverage and liquidity between IPO and mature firms can explain the significant one-year IPO underperformance in isolation, even when accounting for the Carhart risk factors. However, we find that when simultaneously controlling for the issue period and the full set of firm-level characteristics in our multivariate RPS-model, we are able to explain IPO underperformance with differences in firm characteristics between IPO and mature firms. We find several of our marketand firm-level characteristics to contribute towards explaining the relative underperformance of IPO 
versus mature firms in an expected way. For example, we generally find higher capital expenditures and higher acquisition rates to be associated with significantly lower returns which is consistent with prior research (Lyandres, Sun, and Zhang, 2008; Brau, Couch, and Sutton, 2012). Consistent with Amihud (2002) and many others, we find evidence of a significant illiquidity premium. Finally, we find cold issue IPO firms to outperform mature firms, confirming previous findings by Helwege and Liang (2004) and Loughran and Ritter (1995).

Our results withstand a battery of robustness tests. First, they are insensitive to variations in our firm characteristics such as for example replacing the Amihud (2002) illiquidity measure for the probability of information-based trading (PIN) (Easley, Kiefer, O’Hara, and Paperman, 1996; Venter and de Jongh, 2006; Brown and Hillegeist, 2007) or to replacing our four separate investment variables by an investment factor constructed parallel to Lyandres, Sun, and Zhang (2008). Second, we find similar results when either replacing the four Carhart (1997) factors by the three Fama-French (1993) factors or when augmenting the Carhart factors with the profitability and investment factors introduced by Fama and French (2015). Third, to challenge the ability of our RPS-model to explain IPO underperformance we identify sub-samples based on firm size, time periods, venture capital involvement, and IPO underpricing that show the most severe underperformance during the first year after going public. Results show that our full RPS-model is able to explain the one-year underperformance of IPO firms across all these sub-samples.

The remainder of the paper is organized as follows. Section 2 presents the sample selection and data. Section 3 analyzes the time horizon over which IPOs underperform. Section 4 presents the main empirical results on multidimensional explanations of the one-year IPO underperformance documented in the previous section. Section 5 concludes.

\section{Sample and Data}

Our sample of IPO firms is based on an updated version of the Field-Ritter dataset of company founding dates as used in Field and Karpoff (2002) and Loughran and Ritter (2004). The dataset consists of 10,145 U.S. companies going public between January 1975 and December 2014. We exclude all unit 
offerings, American Depository Receipts (ADRs), closed-end funds, Real Estate Investment Trusts (REIT's), and partnerships. We also exclude firms in regulated industries, i.e., financial firms (SIC codes 6000-6999) and utilities (SIC codes 4900-4999). Following Ritter (1991), we only consider IPOs with an offering price of at least $\$ 1 .{ }^{4} \mathrm{We}$ also exclude 224 companies for which the IPO month differs from the first month with stock price data available on the Center for Research in Security Prices (CRSP) database. All these filters result in a final sample of 7,487 U.S. IPOs.

Information on monthly stock prices for all issuing and non-issuing firms is obtained from the CRSP database over the respective period. Applying the filters explained above leads to stock price and return data for 12,906 U.S. companies from 1975 to 2014, of which 7,487 firms went public during this period and are thus classified as IPO firms. For the remaining 5,419 companies the first five years of observations available on CRSP are dropped to ensure that these firms are mature and do not dilute the statistical analysis. Thus, mature firms have been listed for a minimum of five years when entering the sample and their initial issuing date is either unknown or before 1975.

Data on the four Carhart (1997) factors are obtained from Kenneth R. French's data library. ${ }^{5}$ Data on the size $(S M B)$, value-growth $(H M L)$, and momentum $(M O M)$ factors can be readily downloaded from the website. The $R M R F$ factor is constructed as the value-weighted return of all CRSP firms in excess of the risk-free rate. Financial data on our sample firms, issuing and mature, is obtained from Compustat. The variables are explained in Section 4.1 below. To estimate the Amihud (2002) illiquidity measure and respective controls, daily information on stock prices, returns, and share volume are extracted from CRSP. Data from the Compustat historical segments database is used to determine the level of international business activity of each firm. Finally, construction of PIN relies on files provided by Stephen Brown (Brown and Hillegeist, 2007) which refer to the Venter and de Jongh (2006) model. ${ }^{6}$ U.S. recession periods are identified based on the National Bureau of Economic Research's business cycle dates.

\footnotetext{
${ }^{4}$ We find similar results, if we only consider IPOs with an offering price of at least $\$ 5$.

${ }^{5}$ The data can be downloaded at: http://mba.tuck.dartmouth.edu/pages/faculty/ken.french/ data_library.html

${ }^{6}$ The files can be downloaded at: http://scholar.rhsmith.umd.edu/sbrown/pin-data 


\section{Over which time horizon do IPOs underperform?}

\subsection{The RPS-regression model}

We assess the long-term performance of IPO firms using the "regression-based portfolio sorts" (or RPS) approach of Hoechle, Schmid, and Zimmermann (2016). The RPS-model involves estimating on the firm level a pooled OLS regression with Driscoll and Kraay (1998) standard errors. Therefore, its estimation results are heteroscedasticity consistent and robust to very general forms of cross-sectional and temporal dependence. In fact, Hoechle, Schmid, and Zimmermann (2016) show both theoretically and empirically, that their regression-based technique is capable to perfectly replicate the results of the traditional calendar time portfolio approach in a single step rather than in two. Consequently, the RPSmodel has the same statistical properties as the traditional portfolio sorts approach while allowing for the inclusion of continuous and multivariate investor characteristics in the analysis. ${ }^{7}$ This is the RPSmodel's most important advantage over the widely used BHAR approach (e.g., Bessembinder and Zhang, 2013; Gompers and Lerner, 2003; Loughran and Ritter, 1995) which is not robust to cross-sectional dependence (Fama, 1998). Moreover, the RPS-model resolves Loughran and Ritter's (2000) critique that by equally weighing each time period instead of each observation the portfolio sorts approach has lower power to detect abnormal returns. By employing an OLS regression, the RPS-model overcomes this problem.

The dependent variable, $y_{i t}$, in all our RPS-models is the firms' quarterly excess return over the next quarter. By lagging all explanatory variables by one quarter, we mitigate endogeneity concerns. Our basic regression specification consists of pooled OLS regressions with the following structure:

$$
y_{i t}=\left(\left(\boldsymbol{p}_{i t} \otimes z_{i t}\right) \otimes \boldsymbol{x}_{\boldsymbol{t}}\right) \beta+v_{i t}
$$

\footnotetext{
${ }^{7}$ Hence, the RPS-approach resolves a major problem not yet addressed in prior research on long-term performance evaluation (see Kothari and Warner, 2008) or panel data estimation procedures such as those surveyed in Petersen (2009). In particular, note that the Fama and MacBeth (1973) approach, which is mainly covered and strongly advocated by Petersen (2009), is limited to the analysis of (excess) returns and does not allow for a decomposition of the risk-adjusted performance (see Hoechle, Schmid, and Zimmermann (2016) for a discussion).
} 
Vector $\boldsymbol{p}_{i t}$ contains a constant and a dummy variable, $D_{i t}^{\tau}$, that equals one if the company is classified as IPO firm and zero otherwise. We classify firms as IPO firm during the first $\tau$ years after going public. Hence, vector $\boldsymbol{p}_{i t}$ is defined as follows throughout our entire analysis:

$$
\boldsymbol{p}_{i t}=\left[1 D_{i t}^{\tau}\right]
$$

Vector $\boldsymbol{x}_{t}$ includes a set of market risk factors to determine the risk-adjusted performance of IPO firms. We rely on the Carhart (1997) four factor model. Hence, vector $\boldsymbol{x}_{t}$ is defined as:

$$
\boldsymbol{x}_{t}=\left[\begin{array}{lllll}
1 & R M R F_{t} & S M B_{t} & H M L_{t} & M O M_{t}
\end{array}\right]
$$

where $R M R F_{t}$ is constructed as the value-weighted return of all CRSP firms in excess of the risk-free rate (the market factor), $S M B_{t}$ is the return on a zero-investment size portfolio, and $H M L_{t}$ and $M O M_{t}$ denote the returns on a zero-investment book-to-market and momentum portfolio, respectively.

Firm characteristics are included in vector $\mathbf{z}_{i t}$. We change and extend the composition of this vector throughout our analysis to include various company-level and market-wide variables put forward in previous research as potential explanations for the apparent underperformance of IPO firms. Vector $\mathbf{z}_{i t}$ includes a constant and a varying set of $M$ firm characteristics $\mathbf{z}_{m, i t}(m=1, \ldots, M)$ :

$$
z_{i t}=\left[\begin{array}{llll}
1 & z_{1, i t} & \ldots & z_{M, i t}
\end{array}\right]
$$

The variables in vectors $\boldsymbol{p}_{i t}$ and $\boldsymbol{z}_{i t}$ are allowed to vary across both the time dimension and the cross-section. In contrast, the risk factors in vector $\boldsymbol{x}_{t}$ vary over time, but not across firms.

\subsection{Empirical analysis}

In this paper, we analyze IPO performance over varying time horizons ranging from one to 40 quarters. For space reasons, we restrict the tabulated results to one, two, three, four and five years after going public. To the best of our knowledge, there is no prior study investigating explicitly the time horizon over which IPO firms underperform. We analyze IPO long-term performance using the following RPS-regression specification: 


$$
\begin{array}{rllll}
y_{i t} & =\beta_{0}+\beta_{5} \times & D_{i t}^{\tau} & \\
& +\beta_{1} \times R M R F_{t}+\beta_{6} \times & \left(D_{i t}^{\tau} \times R M R F_{t}\right) \\
& +\beta_{2} \times S M B_{t}+\beta_{7} \times & \left(D_{i t}^{\tau} \times S M B_{t}\right) & \\
& +\beta_{3} \times H M L_{t}+\beta_{8} \times & \left(D_{i t}^{\tau} \times H M L_{t}\right) & \\
& +\beta_{4} \times M O M_{t}+\beta_{9} \times\left(D_{i t}^{\tau} \times M O M_{t}\right) & +v_{i t}
\end{array}
$$

where the dependent variable, $y_{i t}$, is the firm's quarterly excess return over the next quarter and $\beta_{0, \ldots, 9}$ are the regression coefficients. $D_{i t}^{\tau}(\tau=1, \ldots, 5)$ is a dummy variable that equals one if the company is classified as IPO firm and zero otherwise. A company is classified as IPO firm during its first $\tau$ years after going public. We consider time horizons, $\tau$, of one, two, three, four, and five years. $R M R F_{t}, S M B_{t}$, $H M L_{t}$, and $M O M_{t}$ are the Carhart risk factors as defined in Section 3.1 above.

The results from estimating five alternative models with $\tau=1, \ldots, 5$ are reported in Table 1 . Each model is subdivided into two columns: The column "Mature" presents the coefficient estimates and tstatistics (in parentheses) for mature companies that have been listed for a minimum of five years $\left(\hat{\beta}_{0, \ldots, 4}\right.$ in equation 5). The constant in this column, i.e., the $\hat{\beta}_{0}$ coefficient estimate, represents the riskadjusted performance of mature firms and the four coefficient estimates on the risk factors $R M R F, S M B$, $H M L$, and $M O M$ are the risk factor exposures of mature firms. The column " $\triangle$ (IPO-Mature)" contains a full set of interaction terms between the IPO dummy and the risk factors (or the regression constant). The corresponding regression coefficients indicate by how much the risk-adjusted performance $\left(\hat{\beta}_{5,}\right)$ and the factor risk exposures $\left(\hat{\beta}_{6, \ldots, 9}\right)$ of IPO firms differ from those of mature companies. When estimating regression (5), we are primarily interested in the coefficient estimate for the IPO dummy $\left(\hat{\beta}_{5}\right)$. If it is negative and significantly different from zero, this indicates that the risk-adjusted performance of IPO firms is worse than that of more mature companies.

The results in Table 1 show that while the coefficient estimate for $D_{i t}^{\tau}$ is negative for all five IPO definitions, it is significant only if IPO firms are defined as firms going public within the last year or the last two years, respectively. In contrast, by referring to IPO firms as companies whose initial public offering occurred within the last three, four, or five years, the coefficient estimate for the IPO dummy becomes insignificant. Moreover, the results in Table 1 show that the "Beta" of IPO firms is significantly higher than that of more mature companies and that IPO firms have a significantly smaller exposure to 
the $H M L_{\mathrm{t}}$ factor than older companies. These results hold for all IPO definitions considered in the table. The latter finding confirms the growth-stock nature of IPOs which has been shown to explain part of the IPO underperformance (e.g., Brav and Gompers, 1997; Brav, Geczy, and Gompers, 2000; Gompers and Lerner, 2003). However, over shorter time horizons of one and two years we continue to find an economically large and statistically significant underperformance of IPO firms.

To provide a more complete picture of the relation between time horizon and IPO performance, Figure 1 displays the evolution of the coefficient estimate for the IPO dummy when regression (5) is estimated with IPO firm definitions ranging from "firms going public within the last quarter" to "firms going public within the last 10 years". Most importantly, the figure reveals that IPO underperformance peaks one year after going public and then gradually decreases over the subsequent years corroborating the results from Table 1. In the first four quarters after going public, risk-adjusted quarterly returns of IPO firms are $2.375 \%$ smaller than those of mature firms. This translates into an annual underperformance of more than 10 percent.

\subsection{Sub-sample tests}

Several prior studies reveal differences in IPO long-term underperformance with regard to firm size, time period analyzed, venture capital involvement, and the degree of IPO underpricing. In this subsection, we attempt to identify sub-samples with the most severe underperformance in order to challenge the ability of our RPS-model to explain IPO underperformance in subsequent tests. Ritter (1991), Loughran and Ritter (1995), and Gao, Ritter, and Zhu (2013) all find small-firm IPOs to exhibit worse long-term performance than large-firm IPOs. Gao, Ritter, and Zhu (2013) show that in the period 19802009 small-firm IPOs underperform by an average of $17.3 \%$ over three years after going public, while large-firm IPOs even outperform style-matched mature firms over the same period. Hence, we split our sample into small and large IPO (and mature) firms according to whether they are above or equal to or below the median market capitalization. As IPO firms are, on average, substantially smaller than mature firms, we calculate median values separately for IPO firms and for mature companies. Model (1) in Table 2 shows results from estimating regression specification (5) separately for small (Panel A) and 
large firms (Panel B). We focus on the first year after going public which shows the highest underperformance for the full sample of IPOs (see Table 1), but also for the subsets of small and large IPOs as shown in Table A.1 in the appendix. While the structure of the estimated model is identical to that reported in Table 1, we only report the coefficient estimates of the constant and the constant interacted with the IPO dummy $D_{i t}^{\tau}$ (i.e., $\hat{\beta}_{0}$ and $\hat{\beta}_{5}$ in equation 5) in Table 2. Coefficient estimates for the risk factors $(R M R F, S M B, H M L$ and $M O M)$ and the respective interaction terms with the IPO dummy are omitted for brevity reasons. Our results confirm the findings of Gao, Ritter, and Zhu (2013) that smallfirm IPOs perform worse than large-firm IPOs. Specifically, we find small-firm IPOs to underperform small mature firms over the first year after going public by a risk-adjusted $3.419 \%$ per quarter which is significantly different from zero at the $1 \%$ level. In contrast, results in Panel B show no significant underperformance of large-firm IPOs compared to large mature companies - even in the first year after going public.

Ritter and Welch (2002), among others, show the sensitivity of results with regard to the time period analyzed. Specifically, they argue that the time-variation in issuing activity, underpricing, and long-run underperformance of IPOs deserves more attention. They find that the long-term performance of IPOs is highly sensitive to the choice of time period analyzed, varying from a style-adjusted threeyear underperformance of $74.2 \%$ to an outperformance of $51.3 \%$ based on annually starting three-year time periods between 1980 and 2001. Gao, Ritter, and Zhu (2013) report a significant drop in U.S. IPO activity, in particular for small IPOs, after the burst of the internet bubble in 2000. Figure A.1 in the appendix shows the annual number of companies going public in the United States from 1975 to 2014 and confirms the general pattern reported in Gao, Ritter, and Zhu (2013). Based on this development, the question arises as to whether the long-term performance of IPOs has changed as well. Hence, we split our sample period into two sub-samples, 1975-2000 and 2001-2014. The results are reported in Model (2) in Table 2. In the first year after going public, we find a similar underperformance across the two time periods which is statistically significant at the $5 \%$ level in both cases. However, when analyzing all five alternative time horizons from one to five years after the IPO, reported in Table A.2 in the appendix, we find evidence for a substantial decrease in IPO underperformance after the burst of the internet bubble in 2000. While IPO underperformance stayed economically meaningful (at $1.48 \%$ per 
quarter) and statistically significant at the $1 \%$ level even for five-year post-IPO periods in the 19752000 period (Panel A), there is no evidence of significant IPO underperformance beyond one year after going public in the post-2000 period (Panel B). Consistent with previous results in Table 1 and Model (1) of Table 2, IPO underperformance peaks one year after going public in both time periods.

Brav and Gompers (1997) show that venture-backed IPO firms perform significantly better than nonventure-backed IPOs. Using a Fama-French (1993) three-factor model, they find that long-term underperformance disappears for venture-backed IPO companies, while it persists for nonventure-backed firms. To test for differences in IPO underperformance related to venture capital involvement, we split our IPO sample based on whether an IPO firm is backed by a venture capitalist or not. Model (3) in Table 2 shows results from estimating regression specification (5) separately for venture-backed (Panel A) and nonventure-backed (Panel B) IPO firms in comparison to the whole sample of mature firms. Consistent with Brav and Gompers (1997), we find a significant underperformance associated with nonventure-backed IPOs over the first year after going public, but no significant difference in the performance of venture-backed IPO firms and mature companies. This finding is further strengthened by results presented in Table A.3 in the appendix: Nonventure-backed IPO firms significantly underperform mature companies over the entire period of up to five years after going public, while we find no significant difference between the performance of venture-backed IPOs and mature firms for all five alternative post-IPO periods.

Finally, there is a large body of literature documenting an underpricing of IPOs, i.e., a positive return from the offer price to the closing price of the first trading day (e.g., Ritter, 1984, 1987; Rock, 1986; Beatty and Ritter, 1986; Carter and Manaster, 1990; Loughran and Ritter, 2004). To investigate whether IPO long-term performance is related to underpricing, we split our IPO sample based on the median first-day return. IPO firms with a first-day return above or equal to the median of $6.19 \%$ are classified as highly underpriced and firms below the median as IPOs with low underpricing. Model (4) in Table 2 shows results from estimating regression specification (5) separately for IPO firms with high underpricing (Panel A) and low underpricing (Panel B) in comparison to the whole sample of mature firms over the first year after going public. Results indicate no relevant differences between the two sub- 
samples. IPO firms with high and low underpricing significantly underperform mature firms over the first year after going public. When inspecting the pattern over the first five years after going public in Table A.4 in the appendix, we find IPO underperformance to persist for up to five years post-issue for low underpricing firms, but to be restricted to the first year post-issue for high underpricing firms. Still, consistent with results in Tables A.1 to A.3, we find the largest underperformance in the first year after going public. Hence, for all of these sub-samples, in particular small IPO firms and nonventure-backed IPOs, the first year after going public will serve as a strong robustness test for the capability of our RPSmodel to explain IPO underperformance.

\section{Explaining IPO underperformance}

\subsection{Variable construction}

Based on previous research, we consider the following firm characteristics as potential determinants of IPO underperformance. Loughran and Ritter (1995) and Helwege and Liang (2004) document that firms going public during periods of high issuing activity perform worse than firms going public in a cold market environment. Hence, we define two dummy variables, HOT and COLD, which are set to one for firms going public during a hot or cold issue period, respectively. For this purpose, the IPO sample is divided into three sub-samples based on whether the company went public during a hot, neutral or cold market environment. Quarters are ranked based on the number of IPOs taking place. The top quartile of quarters with the highest number of IPOs is then classified as hot, the lower half of quarters as cold and the remaining quarters as neutral issue periods. In the analyzed sample, IPOs are classified as $H O T$ if they went public during a quarter with at least 73 other IPOs and as $C O L D$ if they went public during a quarter with at most 33 other offerings. The remaining quarters are classified as neutral. Moreover, we define Recession as a dummy variable which is set to one if a firm went public during a recession period such as defined by the National Bureau of Economic Research. Brau, Couch, and Sutton (2012) and Lyandres, Sun, and Zhang (2008) argue that higher investments and an increased acquisition- 
activity of IPO firms explains IPO underperformance. We define Capex/Sales, R\&D/Sales, and Acquisitions/Sales as quarterly capital expenditures, R\&D expenditures, and acquisitions, all scaled by sales. ${ }^{8}$ Eckbo and Norli (2005) suggest a leverage- and liquidity-related explanation for long-term IPO underperformance. Consequently, we calculate Leverage as total assets net of common equity divided by total assets and define two alternative measures of liquidity. Illiquidity is calculated for each stock and for each quarter as the mean-adjusted average ratio of absolute stock return to dollar trading volume (Amihud, 2002). We use the mean-adjusted ratio to control for time trends in the liquidity measure. PIN, the probability of informed trade (Easley, Kiefer, O'Hara, and Paperman, 1996) measures the risk of information-based trading. Following the methodology of Mauer, Wang, Wang, and Zhang (2015), who show that globally diversified IPO firms exhibit better long-term performance than purely domestic IPOs, we define $I B A$ (international business activity) as a dummy variable which is equal to one if a firm reports either foreign sales or exports. To mitigate the effect of outliers, all ratios are winsorized at the $1^{\text {st }}$ and $99^{\text {th }}$ percentiles.

\subsection{Descriptive statistics}

Table 3 reports descriptive statistics (mean, median, $25^{\text {th }}$, and $75^{\text {th }}$ percentiles) on all these variables for the set of 7,487 IPO and 5,419 mature firms, respectively. As results presented in Section 3.2 above show that IPO underperformance steadily increases over the first year after going public, descriptive statistics on IPO firms are based on the first year after going public.

An analysis of the differences between IPO and mature firms may provide some preliminary evidence as to which factors might be relevant for explaining IPO underperformance in the subsequent Section 4.3. In line with prior research, we find IPO firms to be smaller on average and to have higher market-to-book ratios than mature firms. Size is measured as market capitalization in millions of 2014 U.S. dollars. The median market-to-book ratio of IPO firms amounts to 2.37 as compared to 1.25 for mature firms. This is in line with findings by Brav and Gompers (1997), Brav, Geczy, and Gompers (2000), and Gompers and Lerner (2003) showing that accounting for size and value/growth factors in a

\footnotetext{
${ }^{8}$ Our measure of acquisition spending is based on Compustat and only includes acquisitions paid in cash, neglecting stock-based acquisitions.
} 
Fama-French three-factor model fully explains IPO underperformance of three- to five-year time periods.

IPO firms exhibit both higher capital and $\mathrm{R} \& \mathrm{D}$ expenditures, and undertake more or larger acquisitions. Thus, differences in acquisition- and investment-behavior may also contribute towards explaining IPO underperformance, as suggested by Brau, Couch, and Sutton (2012) and Lyandres, Sun, and Zhang (2008). We also find IPO firms to exhibit lower international business activity (IBA) than mature firms. As the likelihood of international expansions grows over the lifecycle of a company, this result is not surprising. Mauer, Wang, Wang, and Zhang (2015) show that globally diversified IPO firms exhibit better long-term performance than purely domestic IPOs. Hence, differences in international business activity may further contribute towards explaining long-term IPO underperformance. Results in Table 3 also suggest that IPO firms operate with lower leverage ratios. This is not surprising as a new issuance of equity reduces leverage (e.g., Alti, 2006). Moreover, IPO firms are usually more restricted in borrowing due to fewer assets and lower current earnings (Eckbo and Norli, 2005). Eckbo and Norli (2005) argue that lower leverage ratios are associated with lower risk and therefore lower expected returns of IPO stocks.

Finally, there is no clear pattern with respect to stock (il)liquidity. The mean (median) value of illiquidity, Amihud's (2002) measure of a stock's illiquidity, is larger (smaller) for IPO versus mature firms. The mean and median PIN of IPO firms are moderately higher during the first year after going public than the mean and median PIN of mature firms. A higher probability of information-based trading is associated with a higher illiquidity of stocks. Hence, there is no clear pattern in illiquidity across the IPO and mature firm samples.

Figure 2 displays the time series of median (average for Acquisitions/Sales and IBA) firm characteristics of IPO firms over five years after going public. The graphs contrast these time series with the median (average for Acquisitions/Sales and IBA) values of all 5,419 mature firms from 1975 to 2014. Consistent with Table 3, the graphs reveal substantial differences in all characteristics over the first year after going public. Most important, all graphs show that differences between IPO and mature firms decline over time. Five years after going public, IPO firms are comparable to mature firms with regard 
to capital expenditures, acquisitions, international business activity, leverage and stock (il)liquidity as measured by illiquidity and PIN. Only R\&D expenses still differ substantially between IPO and mature firms. Hence, if the aggregate of these characteristics is able to explain a significant part of long-term IPO underperformance, we would expect this underperformance to wash out three- to five-years after going public as IPO firms become more similar to mature firms. This is exactly what we find in Table 1.

\subsection{Multivariate analysis using the RPS-model}

In this sub-section, we attempt to explain IPO underperformance by adding various firm characteristics to our RPS-model. Specifically, we extend vector $\boldsymbol{z}_{i t}$ to include various firm characteristics related to the IPO issue period, investment, internationality, and leverage and liquidity. Referring to

results in Section 3, we set $\tau=1$ and define vector $\boldsymbol{p}_{i t}=\left[1 D_{i t}^{1}\right]$ throughout the whole section. The composition of vector $\boldsymbol{x}_{t}$ stays as shown in equation (3). Results for the above specified regressions are reported in Table 4. Similar to Tables 1 and 2, each model estimation is subdivided into two columns: Column "Mature" presents coefficient estimates and t-statistics (in parentheses) for firm characteristics of companies that have been listed for a minimum of five years. Column " $\Delta$ (IPO-Mature)" reports coefficient estimates and t-statistics of interaction terms between the IPO dummy, $D_{i t}^{1}$, and firm characteristics. For brevity, coefficient estimates for the four risk factors (RMRF, $S M B, H M L$, and $M O M)$ and their interaction terms are not reported. Our primary focus is on the coefficient estimate for the IPO dummy. If a firm characteristic, or a set of characteristics, is able to explain IPO underperformance, the coefficient estimate for the IPO dummy, which is reported in the first row of Column " $\Delta$ (IPO-Mature)", will turn insignificant.

The first characteristic examined relates to the market environment during which a firm goes public. Loughran and Ritter (1995) and Helwege and Liang (2004) document differences in the performance of firms going public during hot issue periods as compared to firms going public in cold issue periods. They show that companies going public during periods of high issuing activity perform worse. Hence, we include the dummy variables $H O T$ and $C O L D$ which are set to one for firms going public 
during a hot or cold issue period, respectively, in our vector $\boldsymbol{z}_{i t}$. We also account for general economic condition by adding the dummy variable Recession which is set to one if a firm went public during a recession. In our first specification, vector $\boldsymbol{z}_{i t}$ is then defined as:

$$
\mathbf{z}_{i t}=\left[\begin{array}{llll}
1 & H_{O} & \operatorname{COLD}_{i} & \text { Recession }
\end{array}\right]
$$

Model (1) in Table 4 reports the results. The coefficient estimate for $D_{i t}^{1}$ remains negative and significant at the 5\% level. Hence, the issue period and the economic environment at the time of the IPO cannot explain IPO underperformance. Besides, neither the coefficient estimate of the interaction term between the IPO dummy and HOT nor the coefficient of the interaction term between the IPO dummy and $C O L D$ is significantly different from zero. The coefficient estimate of the interaction between $D_{i t}^{1}$ and Recession is negative, highly statistically significant, and of larger absolute magnitude than the coefficient estimate of Recession. Although this implies a lower performance of IPO firms that went public during a recession, this performance difference is unable to explain the underperformance of IPO firms in comparison to mature firms.

Theoretical models suggest a negative relation between investments and expected returns (e.g., Cochrane, 1991; Carlson, Fisher, and Giammarino, 2004). A related explanation for IPO underperformance in the long run stems from Lyandres, Sun, and Zhang (2008). They argue that IPO firms invest more and consequently achieve lower long-term returns. In addition, Brau, Couch, and Sutton (2012) explain IPO long-term underperformance with an increased acquisition activity of IPO firms. Empirically, acquiring firms are associated with lower long-term returns (e.g., Loughran and Vijh, 1997; Rau and Vermaelen, 1998). Brau, Couch, and Sutton (2012) show that only IPO firms that acquire during the first year after going public underperform. Moreover, Arikan and Stulz (2016) show that acquisition rates are higher during the first years after going public when compared to mature firms. This finding is confirmed in Table 3 which shows that IPO firms, besides having higher capital and R\&D expenditures, undertake more or larger acquisitions than mature firms. It is thus possible that such differences in investment-behavior between IPO and mature firms are responsible for the documented underperformance of IPO firms. Hence, in our next RPS-model specification, we define vector $\boldsymbol{z}_{i t}$ as: 


$$
\mathbf{z}_{i t}=\left[\begin{array}{llll}
1 \operatorname{Capex}_{i, t-1} & R D_{i, t-1} & \operatorname{miRD}_{i, t-1} & \operatorname{Acq}_{i, t-1}
\end{array}\right]
$$

where Capex $_{i, t-1}$ is quarterly capital expenditures scaled by sales, $R D_{i, t-1}$ quarterly $\mathrm{R} \& \mathrm{D}$ expenditures scaled by sales, $m i R D_{i, t-1}$ a dummy variable which is set to one if $R \& D$ expenditures are missing, and to zero otherwise, and $A c q_{i t}$ is defined as the value of quarterly acquisitions scaled by sales. ${ }^{9}$ Results are reported in Model (2) in Table 4. Most important, investments are unable to explain the one-year IPO underperformance. The coefficient estimate for $D_{i t}^{1}$ remains negative and significant at the $1 \%$ level. Moreover, all coefficient estimates of the interaction terms between the IPO dummy and $\operatorname{Capex}_{i, t-1}, R D_{i, t-1}, m i R D_{i, t-1}$, and $A c q_{i, t-1}$ are insignificant. Hence, there is no difference in the performance of IPO and mature firms with respect to capital and R\&D expenditures as well as acquisition activities. However, consistent with prior research, we generally find higher capital expenditures and higher acquisition rates to be associated with significantly lower returns. In unreported results, we find that including an investment factor constructed parallel to Lyandres, Sun, and Zhang (2008), instead of our four separate investment variables, into the regression specification leads to similar results.

Next, we examine differences in internationality as a possible explanation for the one-year underperformance of IPO firms. Mauer, Wang, Wang, and Zhang (2015) show that globally diversified IPO firms perform significantly better over three- and five-year periods after going public than purely domestic IPOs. Our descriptive statistics in Table 3 confirm that IPO firms are, on average, less globally diversified than mature firms. Hence, differences in international business activity may explain (part of) the underperformance of IPO firms in the long run. We define vector $\boldsymbol{z}_{i t}$ as:

$$
z_{i t}=\left[\begin{array}{ll}
1 & I B A_{i}
\end{array}\right]
$$

where $I B A_{i}$ is a dummy variable whether a firm reports either foreign sales or exports, following the methodology in Mauer, Wang, Wang, and Zhang (2015). As IBA is constructed on the basis of yearly data, the dummy variable is equal to one for IPOs if they report international business activity during

\footnotetext{
${ }^{9}$ If R\&D expenditures are not reported, the dummy $m i R D_{i t}$ is set to one and $R D_{i t}$ is set to zero (e.g., Gompers, Ishii, and Metrick, 2010).
} 
their first year after going public. The results are reported in Model (3) in Table 4 and show that controlling for differences in internationality between IPO and mature firms cannot explain the one-year underperformance of IPOs. The coefficient estimate for the IPO dummy remains negative and significant at the $1 \%$ level. Moreover, the coefficient estimate of the interaction term between IBA and the IPO dummy is positive and significant at the 5\% level. Hence, globally diversified IPO firms perform significantly better than domestic IPO firms. This finding supports prior analyses by Mauer, Wang, Wang, and Zhang (2015).

Eckbo and Norli (2005) suggest a liquidity- and leverage-based explanation for IPO underperformance. They argue that the relatively low leverage ratio of IPO firms might be important in explaining IPO underperformance as leverage has a "turbo charging" effect on the factor loadings in a multifactor model. Consequently, they expect IPO stocks to respond stronger to leverage-related risk factors such as the stock market return, credit spread, term spread, or unexpected inflation. They also find that a higher liquidity of IPO stocks reduces systematic risk exposure and thus explains lower expected returns. To investigate their conjecture empirically, they estimate a number of multifactor models including Carhart's (1997) four-factor model augmented with a liquidity-based risk factor and a seven-factor macro model where the size, book-to-market, and momentum factors are replaced with the liquidity-based factor and a set of five macroeconomic risk factors. Their results reveal that IPO firms exhibit significant factor loadings on these liquidity- and leverage-related factors. Most importantly, the alphas of their models are insignificant which indicates that IPO underperformance over a five-year period can be explained by their factor models. To investigate this liquidity- and leverage-based explanation of IPO underperformance, we specify vector $\mathbf{z}_{i t}$ as:

$$
\mathbf{z}_{i t}=\left[\begin{array}{lll}
1 & \text { Lev }_{i, t-1} & \text { Illiquidity } \\
i, t-1
\end{array}\right]
$$

where $L e v_{i, t-1}$ is the book leverage ratio of firm $i$ at the end of quarter $t-1$. Leverage is defined as total assets net of common equity divided by total assets. Illiquidity $y_{i t}$ is calculated for each stock and for each quarter as the mean-adjusted average ratio of absolute stock return to dollar trading volume (Amihud, 2002). We use the mean-adjusted ratio to control for time trends in the liquidity measure, but find similar results without mean-adjustment. Following Amihud (2002), we also include SDRet, defined as 
the standard deviation of daily stock returns in the respective quarter, and RQtr, defined as the stock's return over the last quarter, as additional control variables. Results are reported in Model (4) in Table 4. Most important, the IPO dummy variable switches sign and is now positive and marginally significant. Hence, we find that differences in stock liquidity between IPO and mature firms and the lower leverage of IPO firms have a substantial impact on the one-year performance of IPOs versus mature firms. Amihud (2002) shows that expected stock excess returns include an illiquidity premium. Accordingly, higher illiquidity is associated with higher average stock returns. Results reported in Model (4) in Table 4 confirm this association. For both mature and IPO firms illiquidity has a positive and highly significant impact on excess returns over the next quarter.

Next, to take full advantage of our multivariate RPS-model we jointly include all control variables used in the four specifications of Table 4. Specifically, the full RPS-specification controls for IPO issue periods as well as differences in firm characteristics between IPO and mature firms related to investments, internationality, liquidity and leverage, past returns (RQtr), and stock volatility (SDRet). Consequently, vector $\boldsymbol{z}_{i t}$ is specified as displayed in equation (10).

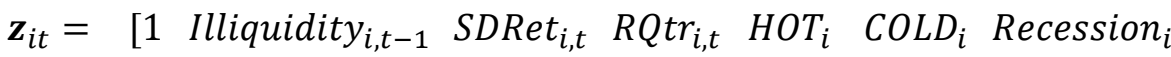

$$
\begin{aligned}
& \text { Capex } \left._{i, t-1} R_{i, t-1} \operatorname{miRD}_{i, t-1} \text { Acq }_{i, t-1} \text { Lev }_{i, t-1} I B A_{i}\right]
\end{aligned}
$$

The results from this specification are reported in Model (1) of Table 5. Most important, these results show that the coefficient estimate of the IPO dummy turns insignificant and our full RPS-model can thus explain the one-year underperformance of IPO firms. Moreover, the economic magnitude of the coefficient estimate of the IPO dummy decreases. In Model (1) of Table 5, the coefficient estimate for the IPO dummy indicates a risk-adjusted quarterly underperformance of $0.741 \%$ compared to $2.375 \%$ without any controls (see Table 1). The results in Table 5 also suggest that in our full RPSmodel cold issue IPO firms outperform mature firms. The coefficient estimate of the interaction term between $C O L D$ and the IPO dummy is positive and significant. This confirms findings by Helwege and Liang (2004) and Loughran and Ritter (1995). Moreover, the negative and highly significant coefficient estimate of the interaction term between the IPO dummy and SDRet indicates that a higher volatility of 
IPO stock returns negatively impacts performance and thus contributes to long-term IPO underperformance. Finally, consistent with prior research, we find evidence of an illiquidity premium.

In Model (2) of Table 5, we replace Illiquidity by an alternative measure of stock liquidity, namely the probability of informed trade (PIN) to test whether our results depend on the choice of the measure of illiquidity. Easley, Kiefer, O'Hara, and Paperman (1996) show that PIN is lower for high volume or liquid stocks. They argue that illiquid stocks are associated with a greater risk of informed trading which is reflected in larger spreads. PIN measures this risk of information-based trading reflecting information on how frequently new information arises on stocks, whether information reflects positive or negative news and the arrival rates of informed and uninformed traders. A higher value of PIN implies a higher illiquidity of the respective stock. The PIN measure we use includes several extensions suggested by Venter and de Jongh (2006) which lead to an improved model fit and higher accuracy of estimating PIN. ${ }^{10}$ The results from using PIN instead of Illiquidity are very similar. Most important, we continue to find a significant illiquidity premium for both mature and IPO firms and there is no evidence of a performance difference across IPO and mature firms with an economically small ( $0.46 \%$ per quarter) and statistically insignificant $(\mathrm{t}=0.18)$ coefficient on the IPO dummy.

Finally, in unreported results we re-estimate the two models in Table 5 including industry fixedeffects based on a Fama-French 12 industry classification and find the results to remain qualitatively unchanged. In other unreported tests, we replace the Carhart (1997) four-factor model by two alternative factors models. The first alternative model is the Fama-French (1993) three-factor model. When replicating Table 1 based on this alternative factor model, we find underperformance to peak two years after going public, at $-1.82 \%$ per quarter, with the second largest underperformance one year after going public (at a quarterly -1.54\%). Beyond year two underperformance drops monotonically. Most important, our full RPS-model, as outlined in equation (10), is able to explain IPO underperformance both in the first year and the first two years after going public. The second alternative model is a six-factor model in which we augment the Carhart (1997) four-factor model by the profitability and investment

\footnotetext{
${ }^{10}$ Extensions include the allowance of interaction between informed and uninformed traders in the model as well as replacing the Poisson assumption of the daily number of buyers and sellers initiated trades with a Poisson Inverse Gaussian assumption. Our PIN data was obtained from files provided by Stephen Brown (Brown and Hillegeist, 2007), which can be downloaded at: http://scholar.rhsmith.umd.edu/sbrown/pin-data.
} 
factors introduced by Fama and French (2015). When replicating Table 1 based on this model, we find underperformance to be statistically significant only in the first year after going public (at $-1.51 \%$ per quarter). Again our full RPS-model from equation (10) is able to explain this IPO underperformance.

\subsection{Robustness tests}

This section presents additional robustness tests on the power of our full RPS-model in explaining IPO underperformance based on various sub-samples. Specifically, we examine whether our full RPSmodel can explain the one-year IPO underperformance in all sub-samples based on firm size, time periods, venture capital involvement, and IPO underpricing. Table 2 shows that there are substantial differences in one-year IPO underperformance from a Carhart (1997) four-factor model with respect to some of these characteristics. A detailed description of the construction and economic reasoning behind all sub-samples can be found in Section 3.3 above.

Table 6 reports results from estimating the RPS-regression separately for all eight sub-samples, based on the full model with Illiquidity included in vector $\boldsymbol{z}_{i t}$ as displayed in equation (10). Model (1) reports results for sub-samples based on firm size, Model (2) based on the time period, Model (3) based on whether there is venture capital involvement, and Model (4) based on the median first-day return (i.e., underpricing). Again, we define IPO firms as firms that have been listed for a maximum of one year, since this represents the time period over which IPO firms underperform most, as discussed in Section 3 above.

Importantly, our full RPS-model is able to explain the one-year underperformance of IPO firms in all eight sub-samples. ${ }^{11}$ This finding strongly supports the power of our RPS based full model specification in explaining IPO underperformance. In each sub-sample the coefficient estimate for the IPO dummy is statistically insignificant when accounting for IPO issue periods as well as differences in firm characteristics between IPO and mature firms related to investments, internationality, liquidity, and leverage as well as past returns and stock volatility. Thus, when jointly accounting for a set of continuous

\footnotetext{
${ }^{11}$ Table 2 shows that large-firm IPOs as well as venture-backed IPOs do not significantly underperform on a risk-adjusted basis. However, for the sake of completeness we still report the respective regression results.
} 
and multivariate firm characteristics, there is no evidence of a significant performance difference between IPO and mature firms across all sub-samples. The full RPS-model consistently explains the longterm underperformance of IPOs.

\section{Conclusion}

Prior research on IPO long-term performance focuses on three- to five-year post-issue time horizons. Ritter (1991) and Loughran and Ritter $(1995,2000)$ find a strong underperformance of IPOs over three- to five-year periods following the issue date. Brav and Gompers (1997), Brav, Geczy, and, Gompers (2000), and Gompers and Lerner (2003) show that IPO firms are strongly tilted towards small and high-growth companies and that the apparent underperformance of IPOs documented in the 1990s disappears when the different risk exposures between IPO and mature firms are accounted for by using multi-factor models such as Carhart (1997).

In the first part of this paper, we show that a sample of 7,487 U.S. IPOs between 1975 and 2014 continue to significantly underperform mature firms in terms of Carhart-alphas over two years, with underperformance peaking one year after going public. Hence, while a Carhart four-factor model and other multi-factor models are able to explain IPO underperformance over three- to five-year post-issue periods by accounting for differences in factor exposure, in particular in terms of size and the book-tomarket, these models fail to explain the relative underperformance of IPO firms over shorter time periods of up to two years.

In the second part of the paper, we apply the regression-based portfolio sorts approach (RPS) of Hoechle, Schmid, and Zimmermann (2016), which allows to decompose the Carhart-alpha into firmspecific characteristics, to explain one-year IPO underperformance using a multitude of market and firm characteristics in a statistically robust setting. We find that when simultaneously controlling for the issue period and a set of firm-level characteristics related to investments, internationality, liquidity, and leverage in our multivariate RPS-model, we are able to explain IPO underperformance with differences in firm characteristics between IPO and mature firms. We challenge our RPS-model by applying it to the 
most severely underperforming IPO sub-samples in terms of firm size, time period, venture capital involvement, and IPO underpricing, and find it to explain IPO underperformance across all sub-samples. 


\section{References}

Alti, A. (2006). How persistent is the impact of market timing on capital structure? Journal of Finance, 61(4), 1681-1710.

Amihud, Y. (2002). Illiquidity and stock returns: cross-section and time-series effects. Journal of Financial Markets, 5(1), 31-56.

Arikan, A. M., and Stulz, R. M. (2016). Corporate acquisitions, diversification, and the firm's life cycle. Journal of Finance, 71(1), 139-194.

Barber, B. M., and Lyon, J. D. (1997). Detecting long-run abnormal stock returns: the empirical power and specification of test statistics. Journal of Financial Economics, 43(3), 341-372.

Beatty, R. P., and Ritter, J. R. (1986). Investment banking, reputation, and the underpricing of initial public offerings. Journal of Financial Economics, 15(1), 213-232.

Bessembinder, H., and Zhang, F. (2013). Firm characteristics and long-run stock returns after corporate events. Journal of Financial Economics, 109(1), 83-102.

Brau, J. C., Couch, R. B., and Sutton, N. K. (2012). The desire to acquire and IPO long-run underperformance. Journal of Financial and Quantitative Analysis, 47(3), 493-510.

Brav, A., and Gompers, P. A. (1997). Myth or reality? The long-run underperformance of initial public offerings: Evidence from venture and nonventure capital-backed companies. Journal of Finance, 52(5), 1791-1821.

Brav, A., Geczy, C., and Gompers, P. A. (2000). Is the abnormal return following equity issuances anomalous? Journal of Financial Economics, 56(2), 209-249.

Brown, S., and Hillegeist, S. A. (2007). How disclosure quality affects the level of information asymmetry. Review of Accounting Studies, 12(2), 443-477.

Carhart, M. M. (1997). On persistence in mutual fund performance. Journal of Finance, 52(1), 57-82.

Carlson, M., Fisher, A., and Giammarino, R. (2004). Corporate investment and asset price dynamics: implications for the cross-section of returns. Journal of Finance, 59(6), 2577-2603.

Carter, R. B., and Manaster, S. (1990). Initial public offerings and underwriter reputation. Journal of Finance, 45(4), 1045-1067. 
Cochrane, J. H. (1991). Production-based asset pricing and the link between stock returns and economic fluctuations. Journal of Finance, 46(1), 209-237.

Dahlquist, M., Martinez, J. V., and Söderlind, P. (forthcoming). Individual investor activity and performance, Review of Financial Studies.

Das, S., Guo, R.-J., and Zhang, H. (2006). Analysts' selective coverage and subsequent performance of newly public firms, Journal of Finance, 61(3), 1159-1185.

Denis, D. J., Denis, D. K., and Yost, K. (2002). Global diversification, industrial diversification, and firm value. Journal of Finance, 57(5), 1951-1979.

Doskeland, T., and Hvide, H. (2011). Do individual investors have asymmetric information based on work experience? Journal of Finance, 66(3), 1011-1041.

Driscoll, J. C., and Kraay, A. C. (1998). Consistent covariance matrix estimation with spatially dependent panel data. Review of Economics and Statistics, 80(4), 549-560.

Easley, D., Kiefer, N. M., O'Hhara, M., and Paperman, J. B. (1996). Liquidity, information, and infrequently traded stocks. Journal of Finance, 51(4), 1405-1436.

Eckbo, В. E., and Norli, Ø. (2005). Liquidity risk, leverage and long-run IPO returns. Journal of Corporate Finance, 11(1), 1-35.

Fama, E. F. (1998). Market efficiency, long-term returns, and behavioral finance. Journal of Financial Economics, 49(3), 283-306.

Fama, E. F., and French, K. R. (1993). Common risk factors in the returns on stocks and bonds. Journal of Financial Economics, 33(1), 3-56.

Fama, E. F., and French, K. R. (1997). Industry costs of equity. Journal of Financial Economics, 43(2), 153-193.

Fama, E. F., and French, K. R. (2015). A five-factor asset pricing model. Journal of Financial Economics, 116(1), 1-22.

Fama, E. F., and MacBeth, J. D. (1973). Risk, return, and equilibrium: Empirical tests. Journal of Political Economy, 81(3), 607-636.

Field, L. C., and Karpoff, J. M. (2002). Takeover defenses of IPO firms. Journal of Finance, 57(5), $1857-1889$. 
Gao, X., Ritter, J. R., and Zhu, Z. (2013). Where have all the IPOs gone? Journal of Financial and Quantitative Analysis, 48(6), 1663-1692.

Gompers, P. A., Ishii, J., and A. Metrick (2010). Extreme governance: An analysis of dual-class firms in the United States, Review of Financial Studies, 23(3), 1051-1088.

Gompers, P. A., and Lerner, J. (2003). The really long-run performance of initial public offerings: The pre-Nasdaq evidence. Journal of Finance, 58(4), 1355-1392.

Helwege, J., and Liang, N. (2004). Initial public offerings in hot and cold markets. Journal of Financial and Quantitative Analysis, 39(3), 541-569.

Hoechle, D., Schmid, M. M., and Zimmermann, H. (2016). Decomposing Performance. Working Paper.

Jaffe, J. F. (1974). Special information and insider trading. Journal of Business, 47(3), 410-428.

Jenkinson, T., Jones, H., Martinez, J. V. (2016). Picking winners? Investment consultants' recommendations of fund managers, Journal of Finance, 71(5), 2333-2370.

Kothari, S.P., and Warner, J.B. (2008). Econometrics of event studies, in: Eckbo, B. Espen (ed.). Handbook of Corporate Finance: Empirical Corporate Finance, Vol. 1, Elsevier/North-Holland, 3-36.

Loughran, T., and Ritter, J. R. (1995). The new issues puzzle. Journal of Finance, 50(1), 23-51.

Loughran, T., and Ritter, J. R. (2000). Uniformly least powerful tests of market efficiency. Journal of Financial Economics, 55(3), 361-389.

Loughran, T., and Ritter, J. R. (2004). Why has IPO underpricing changed over time? Financial Management, 33(3), 5-37.

Loughran, T., and Vijh, A. M. (1997). Do long-term shareholders benefit from corporate acquisitions? Journal of Finance, 52(5), 1765-1790.

Lowry, M., and Schwert, G. W. (2002). IPO market cycles: Bubbles or sequential learning? Journal of Finance, 57(3), 1171-1200.

Lyandres, E., Sun, L., and Zhang, L. (2008). The new issues puzzle: testing the investment-based explanation. Review of Financial Studies, 21(6), 2825-2855.

Lyon, J. D., Barber, B. M., and Tsai, C.-L. (1999). Improved methods for tests of long-run abnormal stock returns. Journal of Finance, 54(1), 165-201. 
Mandelker, G. (1974). Risk and return: the case of merging firms. Journal of Financial Economics, $1(4), 303-335$.

Mauer, D. C., Wang, S., Wang, X., and Zhang, Y. (2015). Global diversification and IPO returns. Journal of Banking and Finance, 58, 436-456.

Petersen, M. A. (2009). Estimating standard errors in financial panel data sets: Comparing approaches. Review of Financial Studies 22, 435-480.

Rau, P. R., and Vermaelen, T. (1998). Glamour, value and the post-acquisition performance of acquiring firms. Journal of Financial Economics, 49(2), 223-253.

Ritter, J. R. (1984). The "hot issue" market of 1980. Journal of Business, 57(2), 215-240.

Ritter, J. R. (1987). The costs of going public. Journal of Financial Economics, 19(2), 269-281.

Ritter, J. R. (1991). The long-run performance of initial public offerings. Journal of Finance, 46(1), 327.

Ritter, J. R., and Welch, I. (2002). A review of IPO activity, pricing, and allocations. Journal of Finance, 57(4), 1795-1828.

Rock, K. (1986). Why new issues are underpriced. Journal of Financial Economics, 15(1), 187-212.

Venter, J.H., de Jongh, D., (2006). Extending the ekop model to estimate the probability of informed trading. Studies in Economics and Econometrics, 30 (2), 25-39. 


\section{Table 1: Over which time horizon do IPOs underperform?}

This table presents coefficient estimates and t-statistics (in parentheses) from running a pooled OLS regression with Discroll-Kraay standard errors based on equation (5). Standard error estimates are heteroskedasticity consistent and robust to cross-sectional dependence and autocorrelation up to four lags. The dependent variable $y_{i t}$ is defined as the firms'

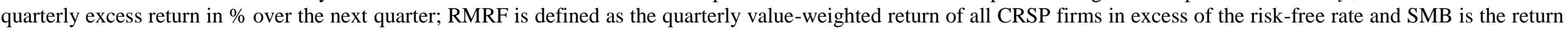
of a zero-investment size portfolio. HML and MOM are the returns of a zero-investment book-to-market and momentum portfolio, respectively. Coefficient estimates and t-values for these risk factors are summarized in the columns labeled Mature. Mature firms have been listed for a minimum of five years. Additionally, the table displays coefficient estimates

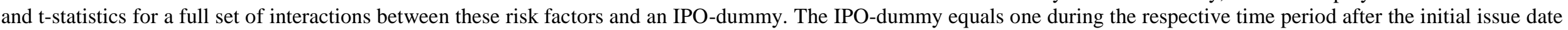
(e.g. up to one year post issue date in model (1), up to two years post issue date in model (2) and so on). Results for the interaction terms are presented in the columns labeled $\Delta$ (IPOMature). The sample comprises an unbalanced panel of 7,487 IPO firms and 5,419 mature firms between 1975 and 2014 . Significance at the $1 \%$, 5\% and $10 \%$ levels are indicated by $* * * * *$ and $*$, respectively.

\begin{tabular}{|c|c|c|c|c|c|c|c|c|c|c|c|c|c|c|c|}
\hline \multirow{4}{*}{$\begin{array}{l}\text { Model } \\
\text { Time post IPO } \\
\text { Constant }\end{array}$} & \multirow{2}{*}{\multicolumn{3}{|c|}{ up to 1 year }} & \multirow{2}{*}{\multicolumn{4}{|c|}{ up to 2 years }} & \multirow{2}{*}{\multicolumn{3}{|c|}{ up to 3 years }} & \multirow{2}{*}{\multicolumn{2}{|c|}{ up to $4 y$}} & \multirow{2}{*}{\multicolumn{3}{|c|}{ up to $5 \mathrm{y}$}} \\
\hline & & & & & & & & & & & & & & & \\
\hline & \multicolumn{2}{|c|}{ Mature } & $\begin{array}{l}\Delta \text { (IPO-Ma- } \\
\text { ture) }\end{array}$ & \multicolumn{2}{|c|}{ Mature } & \multicolumn{2}{|c|}{$\begin{array}{c}\Delta \text { (IPO-Ma- } \\
\text { ture }) \\
\end{array}$} & \multicolumn{2}{|c|}{ Mature } & $\begin{array}{c}\Delta \text { (IPO-Ma- } \\
\text { ture })\end{array}$ & Mature & $\begin{array}{c}\Delta \text { (IPO-Ma- } \\
\text { ture })\end{array}$ & Mature & \multicolumn{2}{|c|}{$\begin{array}{c}\Delta \text { (IPO-Ma- } \\
\text { ture })\end{array}$} \\
\hline & $\begin{array}{l}0.746 \\
(2.50)\end{array}$ & $* *$ & $\begin{array}{l}-2.375 \quad * * * \\
(-2.76)\end{array}$ & $\begin{array}{l}0.746 \\
(2.50)\end{array}$ & $* *$ & $\begin{array}{l}-1.708 \\
(-2.27)\end{array}$ & $* *$ & $\begin{array}{l}0.746 \\
(2.50)\end{array}$ & $* *$ & $\begin{array}{l}-1.081 \\
(-1.54)\end{array}$ & $\begin{array}{l}0.746 \quad * * \\
(2.50)\end{array}$ & $\begin{array}{l}-0.863 \\
(-1.41)\end{array}$ & $\begin{array}{l}0.746 \quad * * \\
(2.50)\end{array}$ & $\begin{array}{l}-0.776 \\
(-1.46)\end{array}$ & \\
\hline RMRF & $\begin{array}{r}0.987 \\
(26.71)\end{array}$ & $* * *$ & $\begin{array}{l}0.250 \quad * * \\
(2.42)\end{array}$ & $\begin{array}{r}0.987 \\
(26.71)\end{array}$ & $* * *$ & $\begin{array}{l}0.190 \\
(2.70)\end{array}$ & $* * *$ & $\begin{array}{r}0.987 \\
(26.71)\end{array}$ & $* * *$ & $\begin{array}{ll}0.189 & * * * \\
(3.19) & \end{array}$ & $\begin{array}{r}0.987 \quad * * * \\
(26.71)\end{array}$ & $\begin{array}{l}0.174 \quad * * * \\
(3.05)\end{array}$ & $\begin{array}{r}0.987 \quad * * * \\
(26.71)\end{array}$ & $\begin{array}{l}0.150 \\
(2.92)\end{array}$ & $* * *$ \\
\hline SMB & $\begin{array}{r}1.095 \\
(17.80)\end{array}$ & $* * *$ & $\begin{array}{l}0.091 \\
(0.44)\end{array}$ & $\begin{array}{r}1.095 \\
(17.80)\end{array}$ & $* * *$ & $\begin{array}{l}0.195 \\
(1.28)\end{array}$ & & $\begin{array}{r}1.095 \\
(17.80)\end{array}$ & $* * *$ & $\begin{array}{l}0.221 \\
(1.60)\end{array}$ & $\begin{array}{r}1.095 \text { *** } \\
(17.80)\end{array}$ & $\begin{array}{l}0.259 \text { ** } \\
(2.23)\end{array}$ & $\begin{array}{r}1.095 \text { *** } \\
(17.80)\end{array}$ & $\begin{array}{l}0.310 \\
(2.80)\end{array}$ & \\
\hline HML & $\begin{array}{l}0.178 \\
(2.84)\end{array}$ & $* * *$ & $\begin{array}{l}-0.959 * * * \\
(-6.05)\end{array}$ & $\begin{array}{l}0.178 \\
(2.84)\end{array}$ & $* * *$ & $\begin{array}{l}-0.932 \\
(-6.94)\end{array}$ & $* * *$ & $\begin{array}{l}0.178 \\
(2.84)\end{array}$ & $* * *$ & $\begin{array}{l}-0.814 * * * \\
(-6.74)\end{array}$ & $\begin{array}{l}0.178 \quad * * * \\
(2.84)\end{array}$ & $\begin{array}{l}-0.727 \quad * * * \\
(-6.91)\end{array}$ & $\begin{array}{l}0.178 \quad * * * \\
(2.84)\end{array}$ & $\begin{array}{l}-0.629 \\
(-7.05)\end{array}$ & \\
\hline MOM & $\begin{array}{l}-0.145 \\
(-1.90)\end{array}$ & $*$ & $\begin{array}{l}0.288 * \\
(1.96)\end{array}$ & $\begin{array}{l}-0.145 \\
(-1.90)\end{array}$ & $*$ & $\begin{array}{l}-0.030 \\
(-0.22)\end{array}$ & & $\begin{array}{l}-0.145 \\
(-1.90)\end{array}$ & $*$ & $\begin{array}{l}-0.126 \\
(-0.96)\end{array}$ & $\begin{array}{l}-0.145 * \\
(-1.90)\end{array}$ & $\begin{array}{l}-0.113 \\
(-0.97)\end{array}$ & $\begin{array}{l}-0.145 * \\
(-1.90)\end{array}$ & $\begin{array}{r}-0.082 \\
(-0.85)\end{array}$ & \\
\hline \# obs. & & $94,96^{\prime}$ & & & 421,5 & & & & 44,64 & & 464,73 & & 482,25 & & \\
\hline \# firms & & 2,906 & & & 12,90 & & & & 2,90 & & 12,90 & & 12,90 & & \\
\hline $\mathrm{R}^{2}$ & & .135 & & & 0.13 & & & & 0.136 & & 0.137 & & 0.136 & & \\
\hline
\end{tabular}


Table 2: Over which time horizon do IPOs underperform? - Sub-sample tests

This table presents coefficient estimates and t-statistics (in parentheses) from running a pooled OLS regression with Driscoll-Kraay standard errors based on equation (5) for a set of sub-samples. Driscoll-Kraay standard errors are heteroskedasticity consistent and robust to cross-sectional dependence and autocorrelation up to four lags. Model (1) analyzes sub-samples based on median firm size as measured by market capitalization, model (2) based on different time periods, model (3) based on whether the IPO firm is backed by a venture capitalist and model (4) based on the median IPO underpricing as measured by the first-day return. The dependent variable $y_{i t}$ is defined as the firms' quarterly excess return in \% over the next quarter. For simplicity reasons only coefficient estimates for the regression constants and the respective interactions are displayed. However, the regression specification is based on the Carhart (1997) four factor model. The following risk factors are included but not displayed. RMRF is defined as the quarterly value-weighted return of all CRSP firms in excess of the risk-free rate and SMB is the return of a zero-investment size portfolio. HML and MOM are the returns of a zero-investment book-to-market and momentum portfolio, respectively. Coefficient estimates and t-values (in parentheses) for the regression constant are summarized in the columns labeled Mature. Mature firms have been listed for a minimum of five years. Additionally, the table displays coefficient estimates and t-statistics for the interaction between the regression constant and an IPO dummy. The IPO dummy equals one during the first year after the initial issue date. Results for the interaction terms are presented in the columns labeled $\Delta$ (IPO-Mature). Significance at the $1 \%, 5 \%$ and $10 \%$ levels are indicated by $* * * * *$ and $*$, respectively.

\begin{tabular}{|c|c|c|c|c|c|c|c|c|c|c|c|}
\hline Model & \multicolumn{3}{|c|}{ (1) } & \multicolumn{3}{|c|}{ (2) } & \multicolumn{2}{|c|}{ (3) } & \multicolumn{3}{|c|}{ (4) } \\
\hline \multirow[t]{2}{*}{ Sub-sample } & \multicolumn{3}{|c|}{ Firm size } & \multicolumn{3}{|c|}{ Time period } & \multicolumn{2}{|c|}{ Venture Capital } & \multicolumn{3}{|c|}{ Underpricing } \\
\hline & Matur & & $\Delta$ (IPO-Mature) & Mature & $\Delta(\mathrm{IPO}-\mathrm{N}$ & ature) & Mature & $\Delta($ IPO-Mature) & Mature & $\Delta(\mathrm{IPO}-\mathrm{N}$ & ature) \\
\hline Panel A & \multicolumn{3}{|c|}{ Small firms } & \multicolumn{3}{|c|}{$1975-2000$} & \multicolumn{2}{|c|}{ VC backed } & \multicolumn{3}{|c|}{ High underpricing } \\
\hline Constant & $\begin{array}{l}-0.823 \\
(-1.67)\end{array}$ & $*$ & $\begin{array}{l}-3.419 \quad * * * \\
(-5.34)\end{array}$ & $\begin{array}{l}0.369 \\
(1.16)\end{array}$ & $\begin{array}{l}-2.315 \\
(-2.27)\end{array}$ & $* *$ & $\begin{array}{l}0.746 \\
(2.50)\end{array}$ & $\begin{array}{l}-2.057 \\
(-1.53)\end{array}$ & $\begin{array}{l}0.746 \\
(2.50)\end{array}$ & $\begin{array}{l}-2.540 \\
(-2.08)\end{array}$ & \\
\hline \# obs. & \multicolumn{3}{|c|}{112,281} & \multicolumn{3}{|c|}{261,171} & \multicolumn{2}{|c|}{376,980} & \multicolumn{3}{|c|}{379,840} \\
\hline \# firms & \multicolumn{3}{|c|}{6,006} & \multicolumn{3}{|c|}{10,998} & \multicolumn{2}{|c|}{10,805} & \multicolumn{3}{|c|}{11,134} \\
\hline $\mathrm{R}^{2}$ & \multicolumn{3}{|c|}{0.107} & \multicolumn{3}{|c|}{0.125} & \multicolumn{2}{|c|}{0.135} & \multicolumn{3}{|c|}{0.134} \\
\hline Panel B & \multicolumn{3}{|c|}{ Large firms } & \multicolumn{3}{|c|}{$2001-2014$} & \multicolumn{2}{|c|}{ non-VC backed } & \multicolumn{3}{|c|}{ Low underpricing } \\
\hline Constant & $\begin{array}{l}1.145 \\
(4.52)\end{array}$ & $* * *$ & $\begin{array}{l}-2.040 \\
(-1.42)\end{array}$ & $\begin{array}{l}1.010 \\
(2.29)\end{array}$ & $\begin{array}{l}-1.799 \\
(-1.99)\end{array}$ & $* *$ & $\begin{array}{l}0.746 \\
(2.50)\end{array}$ & $\begin{array}{l}-2.640 \quad * * * \\
(-4.39)\end{array}$ & $\begin{array}{l}0.746 \\
(2.50)\end{array}$ & $\begin{array}{l}-2.189 \\
(-3.90)\end{array}$ & $* * *$ \\
\hline \# obs. & \multicolumn{3}{|c|}{238,007} & \multicolumn{3}{|c|}{133,796} & \multicolumn{2}{|c|}{383,478} & \multicolumn{3}{|c|}{380,689} \\
\hline \# firms & \multicolumn{3}{|c|}{5,644} & \multicolumn{3}{|c|}{5,400} & \multicolumn{2}{|c|}{11,537} & \multicolumn{3}{|c|}{11,222} \\
\hline $\mathrm{R}^{2}$ & & & & & 158 & & & 30 & & 31 & \\
\hline
\end{tabular}




\section{Table 3: Descriptive statistics}

This table presents descriptive statistics of the following firm characteristics: firm size, as measured by market capitalization, market-to-book ratio, capex scaled by sales, R\&D expenditures and acquisitions scaled by sales as well as leverage, international business activity (IBA), illiquidity as measured by Amihud and PIN, the probability of informed trade. Except firm size, all characteristics are winsorized at the 1st and 99th percentiles. Firm size is reported in millions of 2014 U.S. dollar. Illiquidity is measured as the mean-adjusted average ratio of absolute stock return to dollar trading volume. Book leverage is calculated as total assets net of common equity divided by total assets. IBA represents a dummy variable that is equal to one if a firm has international business activity. The table shows mean, median, 25th and 75th percentile of each characteristic for 7,487 IPO firms and 5,419 mature firms between 1975 and 2014. IPO figures represent firm characteristics over the first year after going public, whereas figures for mature firms are reported for all firms which are listed for a minimum of five years. The two columns compare IPO firm characteristics to characteristics of mature firms.

\begin{tabular}{|c|c|c|c|}
\hline & & \multicolumn{2}{|c|}{ Differences in firm characteristics of IPO and mature firms } \\
\hline & & IPO firms & Mature firms \\
\hline Number of firms & & 7,487 & 5,419 \\
\hline \multirow[t]{4}{*}{ Firm Size } & mean & 533.44 & $3,168.56$ \\
\hline & median & 156.39 & 182.74 \\
\hline & 25th percentile & 56.95 & 41.65 \\
\hline & 75th percentile & 423.35 & $1,064.08$ \\
\hline \multirow[t]{4}{*}{ Market-to-Book } & mean & 3.15 & 1.59 \\
\hline & median & 2.37 & 1.25 \\
\hline & 25th percentile & 1.58 & 0.99 \\
\hline & 75th percentile & 3.76 & 1.75 \\
\hline \multirow[t]{4}{*}{ Capex/Sales } & mean & 0.34 & 0.18 \\
\hline & median & 0.12 & 0.08 \\
\hline & 25th percentile & 0.05 & 0.03 \\
\hline & 75th percentile & 0.33 & 0.17 \\
\hline \multirow[t]{4}{*}{ R\&D/Sales } & mean & 0.37 & 0.11 \\
\hline & median & 0.12 & 0.04 \\
\hline & 25th percentile & 0.02 & 0.01 \\
\hline & 75th percentile & 0.30 & 0.10 \\
\hline \multirow[t]{4}{*}{ Acquisitions/Sales } & mean & 0.10 & 0.05 \\
\hline & median & 0.00 & 0.00 \\
\hline & 25th percentile & 0.00 & 0.00 \\
\hline & 75th percentile & 0.00 & 0.00 \\
\hline \multirow[t]{4}{*}{ IBA } & mean & 0.15 & 0.26 \\
\hline & median & 0.00 & 0.00 \\
\hline & 25th percentile & 0.00 & 0.00 \\
\hline & 75th percentile & 0.00 & 0.00 \\
\hline \multirow[t]{4}{*}{ Leverage } & mean & 0.36 & 0.51 \\
\hline & median & 0.32 & 0.52 \\
\hline & 25th percentile & 0.17 & 0.38 \\
\hline & 75th percentile & 0.54 & 0.65 \\
\hline \multirow[t]{4}{*}{ Illiquidity } & mean & 0.69 & 0.90 \\
\hline & median & 0.45 & 0.39 \\
\hline & 25th percentile & 0.24 & 0.13 \\
\hline & 75th percentile & 0.83 & 1.04 \\
\hline \multirow[t]{4}{*}{ PIN } & mean & 0.24 & 0.22 \\
\hline & median & 0.22 & 0.18 \\
\hline & 25th percentile & 0.16 & 0.12 \\
\hline & 75th percentile & 0.30 & 0.29 \\
\hline
\end{tabular}




\section{Table 4: Firm characteristics and IPO performance}

This table presents coefficient estimates and t-statistics (in parentheses) from running a pooled OLS regression with Driscoll-Kraay standard errors based on equation (1). DriscollKraay standard errors are heteroskedasticity consistent and robust to cross-sectional dependence and autocorrelation up to four lags. The dependent variable $y_{i t}$ is defined as the firms' quarterly excess return in \% over the next quarter. Explanatory variables are based on a Kronecker product of the risk factors RMRF, SMB, HML and MOM and a set of firm characteristics. For simplicity, coefficient estimates for the risk factors and respective interactions are not reported. Firm characteristics are defined as follows. Hot and Cold Market are dummy variables which are set to one for quarters with more than 72.5 IPOs and less than 33 IPOs, respectively. Recession is a dummy variable that is equal to one if a quarter is classified as a recession according to the National Bureau of Economic Research. Capex/Sales and $R \& D / S a l e s$ represent quarterly capital and R\&D expenditures scaled by sales. Missing $R \& D$ is a dummy variable which is set to one for firms which do not report R\&D expenditures and to zero otherwise. Acquisitions/Sales shows the value of quarterly acquisitions scaled by sales. IBA represents a dummy variable that is equal to one if a firm has international business activity. Leverage represents the book leverage which is calculated as total assets net of common equity divided by total assets. Illiquidity is defined as the mean-adjusted average ratio of absolute stock return to dollar trading volume. SDRet and RQtr account for volatility and past returns, respectively. SDRet is calculated as the standard deviation of daily stock returns during the respective quarter and RQtr is the stock return during the last quarter. Coefficient estimates and t-values for these explanatory variables are summarized in the columns labeled "Mature". Mature firms have been listed for a minimum of five years. Additionally, the table displays coefficient estimates and t-statistics of a full set of interaction terms between the explanatory variables and an IPO dummy. The IPO dummy equals one during the first year after the respective initial issue date. Results for the interaction terms are presented in the columns labeled " $\Delta$ (IPO-

Mature)". Model (1) accounts for IPO issue periods, Model (2) for investments, Model (3) for internationality and Model (4) for leverage and liquidity. In each regression specification the respective firm characteristics are included in vector $\mathbf{z}_{\mathrm{it}}$. The sample comprises an unbalanced panel of 7,487 IPO firms and 5,419 mature firms between 1975 and 2014. Significance at the $1 \%, 5 \%$ and $10 \%$ levels are indicated by $* * *, * *$ and $*$, respectively. 


\begin{tabular}{|c|c|c|c|c|c|c|c|c|c|c|c|c|c|c|}
\hline \multirow{3}{*}{$\begin{array}{l}\text { Model } \\
\text { Constant }\end{array}$} & \multicolumn{3}{|c|}{$\begin{array}{c}(1) \\
\text { Issue Period } \\
\end{array}$} & \multicolumn{4}{|c|}{$\begin{array}{c}(2) \\
\text { Investments }\end{array}$} & \multicolumn{3}{|c|}{$\begin{array}{c}\text { (3) } \\
\text { Internationality }\end{array}$} & \multicolumn{4}{|c|}{$\begin{array}{l}\text { (4) } \\
\text { Leverage and Liquidity }\end{array}$} \\
\hline & \multirow{2}{*}{$\begin{array}{l}\text { Mature } \\
0.352 \\
(1.03)\end{array}$} & \multicolumn{2}{|c|}{$\Delta$ (IPO-Mature) } & \multicolumn{2}{|c|}{ Mature } & \multicolumn{2}{|c|}{$\Delta$ (IPO-Mature) } & \multirow{2}{*}{$\begin{array}{c}\text { Mature } \\
0.613 \\
(1.60)\end{array}$} & \multicolumn{2}{|c|}{$\Delta$ (IPO-Mature) } & \multirow{2}{*}{\multicolumn{2}{|c|}{$\begin{array}{l}\text { Mature } \\
-0.314 \\
(-0.41)\end{array}$}} & \multicolumn{2}{|c|}{$\Delta$ (IPO-Mature) } \\
\hline & & $\begin{array}{l}-3.175 \\
(-2.01)\end{array}$ & $* *$ & $\begin{array}{r}2.054 \\
(5.58)\end{array}$ & $* * *$ & $\begin{array}{l}-3.934 \\
(-2.83)\end{array}$ & $* * *$ & & $\begin{array}{l}-2.657 \\
(-2.83)\end{array}$ & $* * *$ & & & $\begin{array}{r}2.751 \\
(1.69)\end{array}$ & $*$ \\
\hline Hot Market & $\begin{array}{l}0.224 \\
(0.37)\end{array}$ & $\begin{array}{r}0.01 \\
(0.01)\end{array}$ & & & & & & & & & & & & \\
\hline Cold Market & $\begin{array}{l}0.533 \\
(1.04)\end{array}$ & $\begin{array}{l}3.545 \\
(1.53)\end{array}$ & & & & & & & & & & & & \\
\hline Recession & $\begin{array}{l}1.023 \\
(0.80)\end{array}$ & $\begin{array}{l}-4.737 \\
(-4.01)\end{array}$ & $* * *$ & & & & & & & & & & & \\
\hline Capex/Sales & & & & $\begin{array}{l}-1.563 \\
(-3.44)\end{array}$ & $* * *$ & $\begin{array}{l}0.417 \\
(0.46)\end{array}$ & & & & & & & & \\
\hline R\&D/Sales & & & & $\begin{array}{l}-0.659 \\
(-1.14)\end{array}$ & & $\begin{array}{l}0.267 \\
(0.24)\end{array}$ & & & & & & & & \\
\hline missing R\&D & & & & $\begin{array}{l}-1.341 \\
(-4.19)\end{array}$ & $* * *$ & $\begin{array}{l}2.006 \\
(1.52)\end{array}$ & & & & & & & & \\
\hline Acquisitions/Sales & & & & $\begin{array}{l}-1.757 \\
(-4.62)\end{array}$ & $* * *$ & $\begin{array}{l}-0.135 \\
(-0.16)\end{array}$ & & & & & & & & \\
\hline IBA & & & & & & & & $\begin{array}{l}0.156 \\
(0.43)\end{array}$ & $\begin{array}{r}1.675 \\
(1.98)\end{array}$ & $* *$ & & & & \\
\hline Leverage & & & & & & & & & & & $\begin{array}{l}-1.121 \\
(-1.34)\end{array}$ & & $\begin{array}{r}0.61 \\
(0.26)\end{array}$ & \\
\hline Illiquidity & & & & & & & & & & & $\begin{array}{l}0.502 \\
(2.19)\end{array}$ & $* *$ & $\begin{array}{l}-0.516 \\
(-0.55)\end{array}$ & \\
\hline SDRet & & & & & & & & & & & $\begin{array}{l}0.176 \\
(0.80)\end{array}$ & & $\begin{array}{l}-1.543 \\
(-3.42)\end{array}$ & $* * *$ \\
\hline RQtr & & & & & & & & & & & $\begin{array}{r}-0.166 \\
(-0.79) \\
\end{array}$ & & $\begin{array}{l}-0.008 \\
(-0.01) \\
\end{array}$ & \\
\hline \# obs. & \multicolumn{3}{|c|}{394,967} & \multicolumn{4}{|c|}{280,417} & \multicolumn{2}{|c|}{377,435} & & \multicolumn{4}{|c|}{315,391} \\
\hline \# firms & \multirow{2}{*}{\multicolumn{3}{|c|}{$\begin{array}{c}12,906 \\
0,136\end{array}$}} & \multirow{2}{*}{\multicolumn{4}{|c|}{$\begin{array}{c}10,761 \\
0,141\end{array}$}} & \multicolumn{3}{|c|}{12,335} & \multicolumn{4}{|c|}{11,298} \\
\hline $\mathrm{R}^{2}$ & & & & & & & & \multicolumn{3}{|c|}{0.138} & \multicolumn{4}{|c|}{0.170} \\
\hline
\end{tabular}


Table 5: Illiquidity and IPO performance

This table presents coefficient estimates and t-statistics (in parentheses) from running a pooled OLS regression with Driscoll-Kraay standard errors based on equation (1). Driscoll-Kraay standard errors are heteroskedasticity consistent and robust to cross-sectional dependence and autocorrelation up to four lags. The dependent variable $y_{i t}$ is defined as the firms' quarterly excess return in \% over the next quarter. Explanatory variables are based on a Kronecker product of the risk factors and a set of firm characteristics. Firm characteristics are defined as in Table 4. Additionally, PIN represents the probability of informed trade, SDRet and RQtr are controls suggested by Amihud (2002) to account for volatility and past returns, respectively. SDRet is calculated as the standard deviation of daily stock returns during the respective quarter and $R Q t r$ is the stock return during the last quarter. Coefficient estimates and t-values for these explanatory variables are summarized in the columns labeled Mature. Mature firms have been listed for a minimum of five years. Additionally, the table displays coefficient estimates and tstatistics for a full set of interactions between the explanatory variables and an IPO dummy. The IPO dummy equals one during the first year after the respective initial issue date. Results for the interaction terms are presented in the columns labeled $\triangle$ (IPO-Mature). Model (1) accounts for illiquidity and model (2) for PIN in addition to all control variables defined before. In each regression specification the respective firm characteristics are included in vector $z_{i t}$. Significance at the $1 \%, 5 \%$ and $10 \%$ levels are indicated by $* * * * *$ and $*$, respectively.

\begin{tabular}{|c|c|c|c|c|c|c|c|c|}
\hline \multirow{3}{*}{$\begin{array}{l}\text { Model } \\
\text { Constant }\end{array}$} & \multicolumn{4}{|c|}{$\begin{array}{c}(1) \\
\text { Illiquidity }\end{array}$} & \multicolumn{4}{|c|}{$\begin{array}{l}(2) \\
\text { PIN }\end{array}$} \\
\hline & \multicolumn{2}{|c|}{ Mature } & \multicolumn{2}{|c|}{$\Delta$ (IPO-Mature) } & \multicolumn{2}{|c|}{ Mature } & \multicolumn{2}{|c|}{$\Delta$ (IPO-Mature) } \\
\hline & $\begin{array}{l}-0.461 \\
(-0.56)\end{array}$ & & $\begin{array}{l}-0.741 \\
(-0.35)\end{array}$ & & $\begin{array}{l}-3.619 \\
(-2.93)\end{array}$ & $* * *$ & $\begin{array}{r}0.459 \\
(0.18)\end{array}$ & \\
\hline Illiquidity & $\begin{array}{l}0.556 \\
(2.36)\end{array}$ & $* *$ & $\begin{array}{l}-0.563 \\
(-0.70)\end{array}$ & & & & & \\
\hline PIN & & & & & $\begin{array}{l}6.321 \\
(3.59)\end{array}$ & $* * *$ & $\begin{array}{l}-3.436 \\
(-0.50)\end{array}$ & \\
\hline SDRet & $\begin{array}{r}0.285 \\
(1.41)\end{array}$ & & $\begin{array}{l}-1.426 \\
(-3.79)\end{array}$ & $* * *$ & $\begin{array}{l}0.621 \\
(3.46)\end{array}$ & $* * *$ & $\begin{array}{l}-1.553 \\
(-4.88)\end{array}$ & $* * *$ \\
\hline RQtr & $\begin{array}{l}-0.237 \\
(-0.98)\end{array}$ & & $\begin{array}{r}0.043 \\
(0.04)\end{array}$ & & $\begin{array}{c}-0.508 \\
(-2.54)\end{array}$ & $* *$ & $\begin{array}{l}-0.282 \\
(-0.19)\end{array}$ & \\
\hline Hot Market & $\begin{array}{c}0.063 \\
(0.09)\end{array}$ & & $\begin{array}{l}0.861 \\
(0.96)\end{array}$ & & $\begin{array}{c}0.555 \\
(0.59)\end{array}$ & & $\begin{array}{r}1.560 \\
(0.87)\end{array}$ & \\
\hline Cold Market & $\begin{array}{c}0.769 \\
(1.16)\end{array}$ & & $\begin{array}{l}4.862 \\
(3.40)\end{array}$ & $* * *$ & $\begin{array}{l}1.641 \\
(1.57)\end{array}$ & & $\begin{array}{l}5.285 \\
(2.20)\end{array}$ & $* *$ \\
\hline Recession & $\begin{array}{c}0.695 \\
(0.59)\end{array}$ & & $\begin{array}{l}-1.805 \\
(-1.37)\end{array}$ & & $\begin{array}{l}1.194 \\
(0.68)\end{array}$ & & $\begin{array}{l}-0.419 \\
(-0.25)\end{array}$ & \\
\hline Capex/Sales & $\begin{array}{l}-1.218 \\
(-2.54)\end{array}$ & ** & $\begin{array}{l}1.154 \\
(1.29)\end{array}$ & & $\begin{array}{l}-0,600 \\
(-1.20)\end{array}$ & & $\begin{array}{l}0.289 \\
(0.26)\end{array}$ & \\
\hline R\&D/Sales & $\begin{array}{l}-0.918 \\
(-1.80)\end{array}$ & * & $\begin{array}{l}0.861 \\
(0.82)\end{array}$ & & $\begin{array}{l}-1.193 \\
(-1.83)\end{array}$ & * & $\begin{array}{l}-0.077 \\
(-0.06)\end{array}$ & \\
\hline missing R\&D & $\begin{array}{l}-1.230 \\
(-4.80)\end{array}$ & $* * *$ & $\begin{array}{l}1.278 \\
(1.27)\end{array}$ & & $\begin{array}{l}-0.973 \\
(-3.00)\end{array}$ & $* * *$ & $\begin{array}{l}0.157 \\
(0.16)\end{array}$ & \\
\hline Acquisitions/Sales & $\begin{array}{l}-0.984 \\
(-3.17)\end{array}$ & $* * *$ & $\begin{array}{l}-1.514 \\
(-1.29)\end{array}$ & & $\begin{array}{l}-1.097 \\
(-2.79)\end{array}$ & $* * *$ & $\begin{array}{l}-1.505 \\
(-1.50)\end{array}$ & \\
\hline Leverage & $\begin{array}{l}0.229 \\
(0.34)\end{array}$ & & $\begin{array}{r}0.734 \\
(0.35)\end{array}$ & & $\begin{array}{c}0.784 \\
(0.98)\end{array}$ & & $\begin{array}{l}2.383 \\
(0.85)\end{array}$ & \\
\hline IBA & $\begin{array}{r}0.149 \\
(0.48)\end{array}$ & & $\begin{array}{l}1.299 \\
(1.54)\end{array}$ & & $\begin{array}{l}0.717 \\
(2.28)\end{array}$ & $* *$ & $\begin{array}{c}0.941 \\
(1.08)\end{array}$ & \\
\hline $\begin{array}{l}\text { \# obs. } \\
\text { \# firms } \\
\mathrm{R}^{2}\end{array}$ & & $\begin{array}{l}43,734 \\
9,760 \\
0.170\end{array}$ & & & & $\begin{array}{r}156,02 \\
7,560 \\
0.163\end{array}$ & & \\
\hline
\end{tabular}




\section{Table 6: Robustness tests based on sub-samples}

This table presents coefficient estimates and t-statistics (in parentheses) from running a pooled OLS regression with Driscoll-Kraay standard errors based on equation (1) for a set of sub-samples. Driscoll-Kraay standard errors are heteroskedasticity consistent and robust to cross-sectional dependence and autocorrelation up to four lags. Model (1) analyzes sub-samples based on median firm size as measured by market capitalization, model (2) based on different time periods, model (3) based on whether the IPO firm is backed by a venture capitalist and model (4) based on the median IPO underpricing as measured by the first-day return. The dependent variable $y_{i t}$ is defined as the firms quarterly excess return in \% over the next quarter. For simplicity reasons only coefficient estimates for the regression constants and the respective interactions are displayed. However, the regression specification is based on the Carhart (1997) four factor model including the risk factors RMRF, SMB, HML and MOM as defined in Table 2 and a full set of control variables. Control variables account for issue periods, investments, leverage, internationality, illiquidity as well as past returns and volatility such as defined in Tables 4 and 5. Coefficient estimates and t-values (in parentheses) for the regression constant are summarized in the columns labeled Mature. Mature firms have been listed for a minimum of five years. Additionally, the table displays coefficient estimates and t-statistics for the interaction between the regression constant and an IPO dummy. The IPO dummy equals one during the first year after the initial issue date. Results for the interaction terms are presented in the columns labeled $\Delta$ (IPO-Mature). Significance at the $1 \%$, $5 \%$ and $10 \%$ levels are indicated by $* * *, * *$ and $*$, respectively.

\begin{tabular}{|c|c|c|c|c|c|c|c|c|c|}
\hline \multirow{3}{*}{$\begin{array}{l}\text { Model } \\
\text { Sub-sample }\end{array}$} & \multicolumn{3}{|c|}{ (1) } & \multicolumn{2}{|c|}{ (2) } & \multicolumn{2}{|c|}{ (3) } & \multicolumn{2}{|c|}{ (4) } \\
\hline & \multicolumn{3}{|c|}{ Firm size } & \multicolumn{2}{|c|}{ Time period } & \multicolumn{2}{|c|}{ Venture Capital } & \multicolumn{2}{|c|}{ Underpricing } \\
\hline & Matur & & $\begin{array}{l}\begin{array}{l}\Delta \text { (IPO-Ma- } \\
\text { ture })\end{array} \\
\end{array}$ & Mature & $\begin{array}{l}\text { (IPO-Ma- } \\
\text { ture })\end{array}$ & Mature & $\begin{array}{l}\text { (IPO-Ma- } \\
\text { ture })\end{array}$ & Mature & $\begin{array}{c}\Delta(\text { IPO-Ma- } \\
\text { ture })\end{array}$ \\
\hline Panel A & \multicolumn{3}{|c|}{ Small firms } & \multicolumn{2}{|c|}{$1975-2000$} & \multicolumn{2}{|c|}{ VC backed } & \multicolumn{2}{|c|}{ High underpricing } \\
\hline Constant & $\begin{array}{l}-3.911 \\
(-2.80)\end{array}$ & $* * *$ & $\begin{array}{l}0.681 \\
(0.24)\end{array}$ & $\begin{array}{l}1.068 \\
(0.91)\end{array}$ & $\begin{array}{l}-0.492 \\
(-0.19)\end{array}$ & $\begin{array}{l}-0.461 \\
(-0.56)\end{array}$ & $\begin{array}{l}-4.777 \\
(-1.34)\end{array}$ & $\begin{array}{l}-0.461 \\
(-0.56)\end{array}$ & $\begin{array}{l}0.218 \\
(0.08)\end{array}$ \\
\hline \# obs. & \multicolumn{3}{|c|}{51,793} & \multicolumn{2}{|c|}{130,633} & \multicolumn{2}{|c|}{235,741} & \multicolumn{2}{|c|}{237,292} \\
\hline \# firms & \multicolumn{3}{|c|}{3,787} & \multicolumn{2}{|c|}{7,925} & \multicolumn{2}{|c|}{8,101} & \multicolumn{2}{|c|}{8,409} \\
\hline $\mathrm{R}^{2}$ & \multicolumn{3}{|c|}{0.118} & \multicolumn{2}{|c|}{0.155} & \multicolumn{2}{|c|}{0.206} & \multicolumn{2}{|c|}{0.170} \\
\hline Panel B & \multicolumn{3}{|c|}{ Large firms } & \multicolumn{2}{|c|}{$2001-2014$} & \multicolumn{2}{|c|}{ non-VC backed } & \multicolumn{2}{|c|}{ Low underpricing } \\
\hline Constant & $\begin{array}{l}-0.455 \\
(-0.56)\end{array}$ & & $\begin{array}{l}-2.554 \\
(-0.84)\end{array}$ & $\begin{array}{l}-0.485 \\
(-0.70)\end{array}$ & $\begin{array}{l}1.320 \\
(0.35)\end{array}$ & $\begin{array}{l}-0.461 \\
(-0.56)\end{array}$ & $\begin{array}{l}0.970 \\
(0.46)\end{array}$ & $\begin{array}{l}-0.461 \\
(-0.56)\end{array}$ & $\begin{array}{l}-1.285 \\
(-0.52)\end{array}$ \\
\hline \# obs. & \multicolumn{3}{|c|}{155,269} & \multicolumn{2}{|c|}{113,101} & \multicolumn{2}{|c|}{238,573} & \multicolumn{2}{|c|}{237,046} \\
\hline \# firms & \multicolumn{3}{|c|}{4,731} & \multicolumn{2}{|c|}{4,733} & \multicolumn{2}{|c|}{8,684} & \multicolumn{2}{|c|}{8,381} \\
\hline $\mathrm{R}^{2}$ & \multicolumn{3}{|c|}{0.197} & & & & & & \\
\hline
\end{tabular}




\section{Figure 1: Evolution of risk-adjusted IPO underperformance over time}

This figure plots the quarterly risk-adjusted performance difference between IPOs and mature companies over 40 different IPO firm definitions depending on the time horizon within which the firm went public. Risk-adjusted performance differences are measured by the coefficient estimate for the IPO dummy in the regression specification (5). The sample comprises an unbalanced panel of 7,487 IPO firms and 5,419 mature firms (which have been listed for a minimum of five years) between 1975 and 2014.

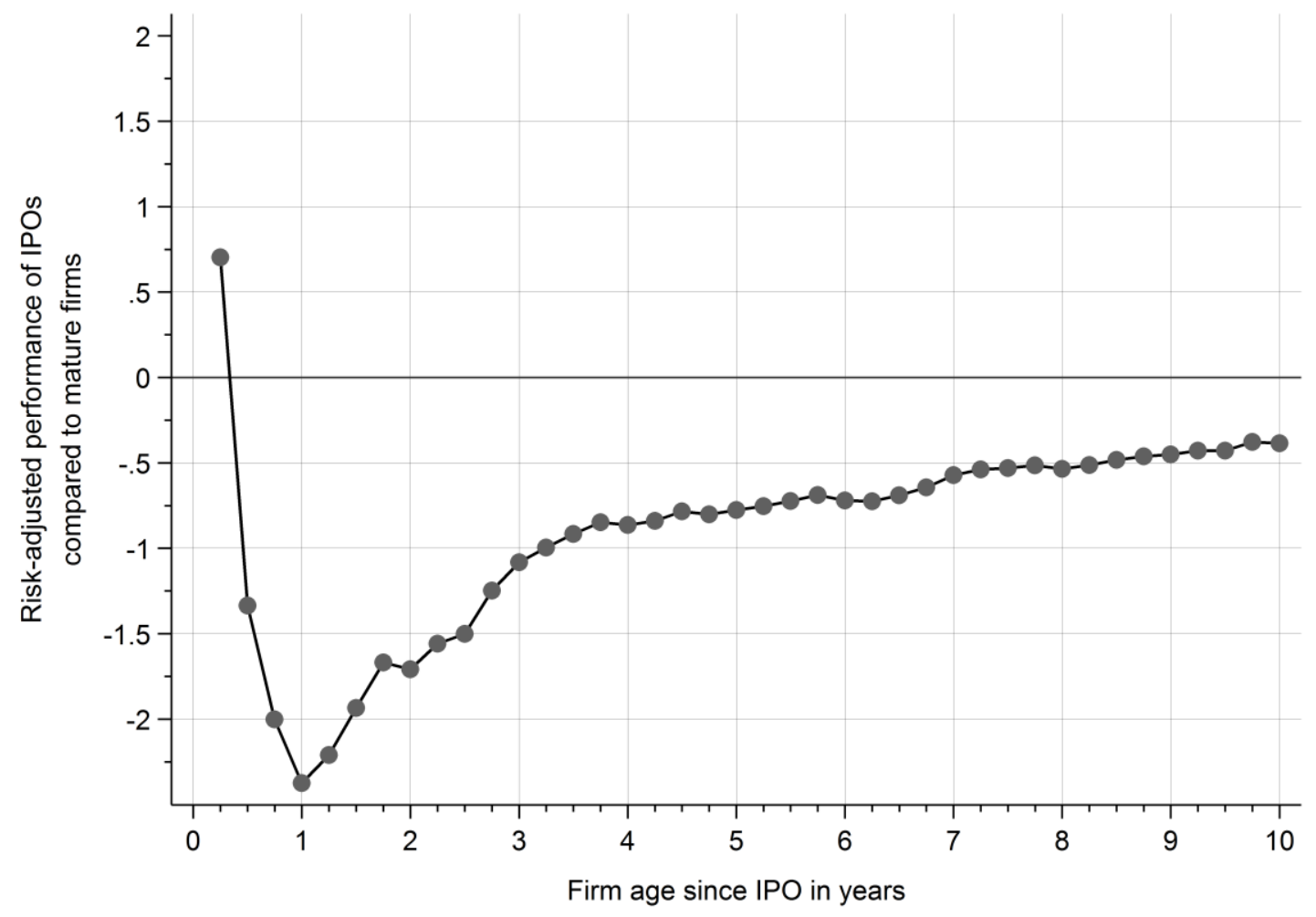




\section{Figure 2: Evolution of characteristics over time}

The charts in this figure plot the time series of the median capital and R\&D expenditures per sales, book leverage, illiquidity as measured by illiqma and PIN as well as the average value of acquisitions per sales and average international business activity for 7,487 IPO firms over five years following their initial issue date. The graphs contrast these time series with the median (average for acquisitions and IBA) values of all 5,419 mature companies from 1975 to 2014. Mature firms have been listed for a minimum of five years. Leverage is calculated as total assets net of common equity divided by total assets. IBA represents a dummy variable that is equal to one if a firm has international business activity. Illiqma is measured as the mean-adjusted average ratio of absolute stock return to dollar trading volume. PIN is the probability of information-based trading.
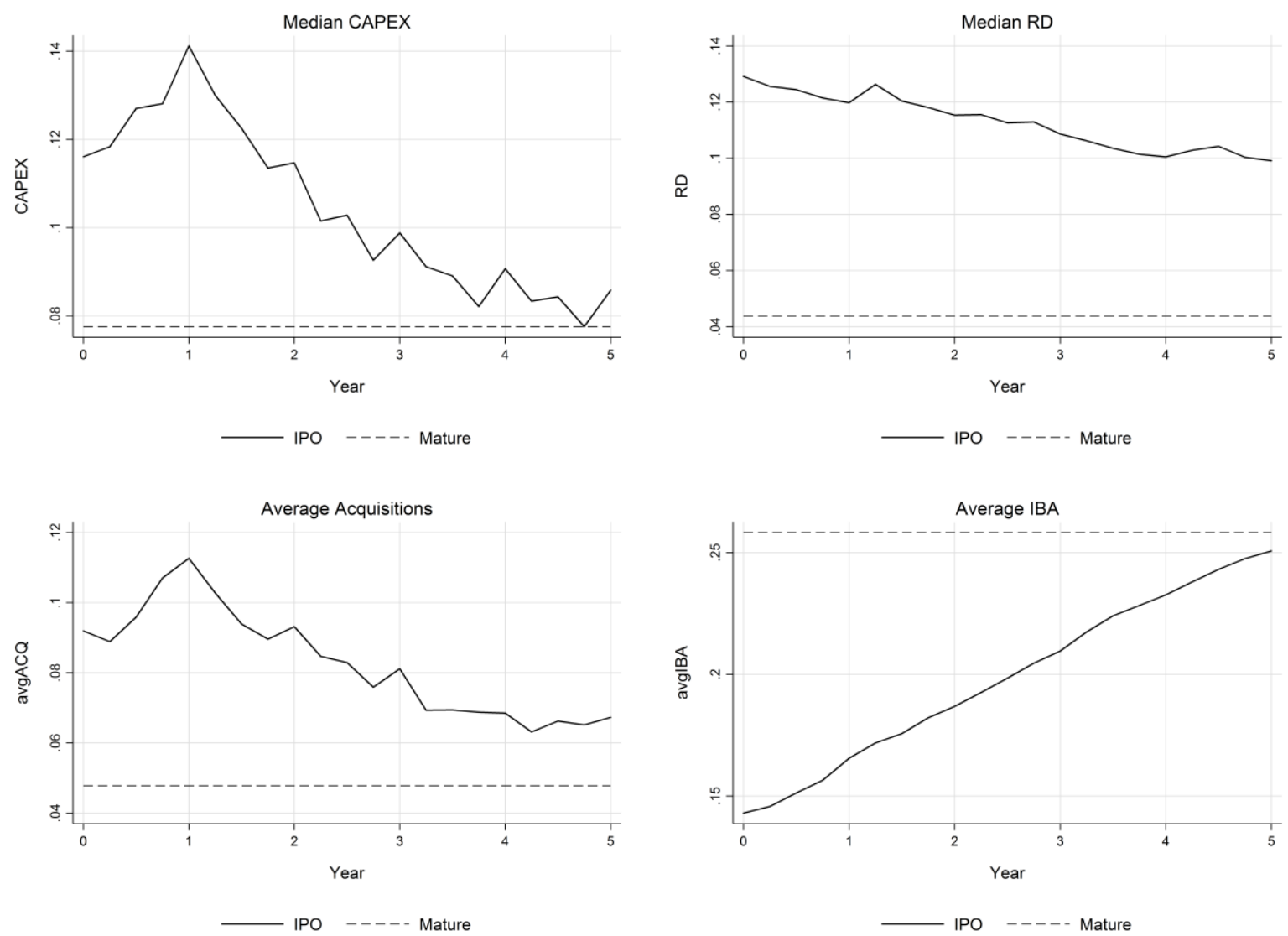


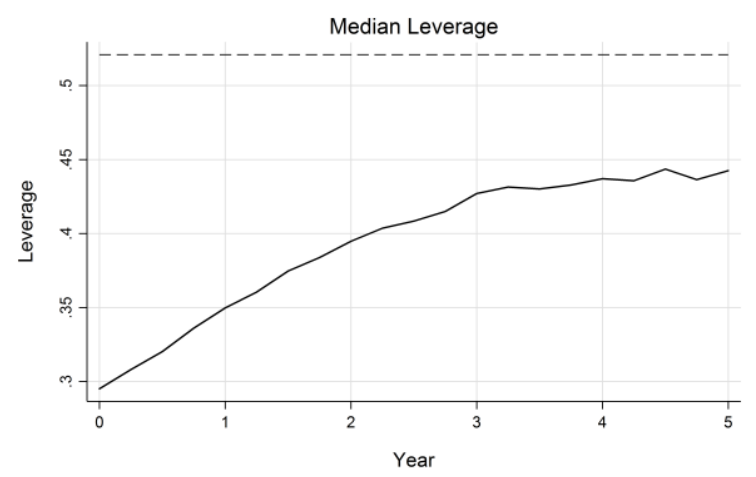

— IPO ----- Mature

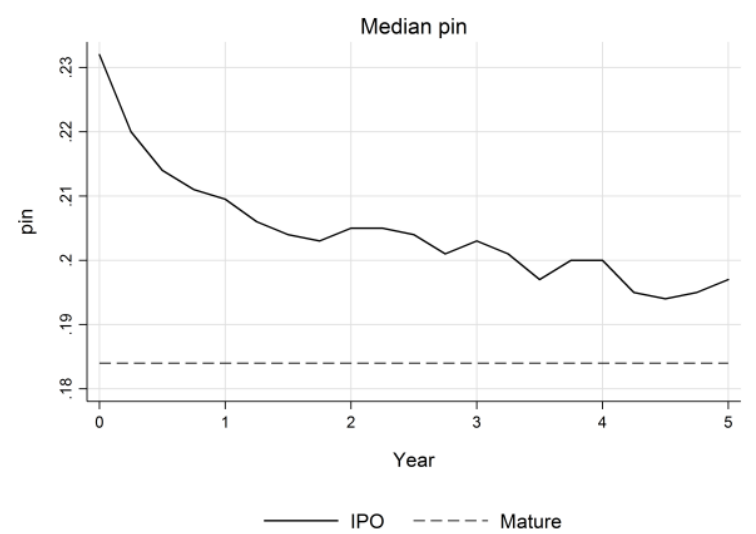

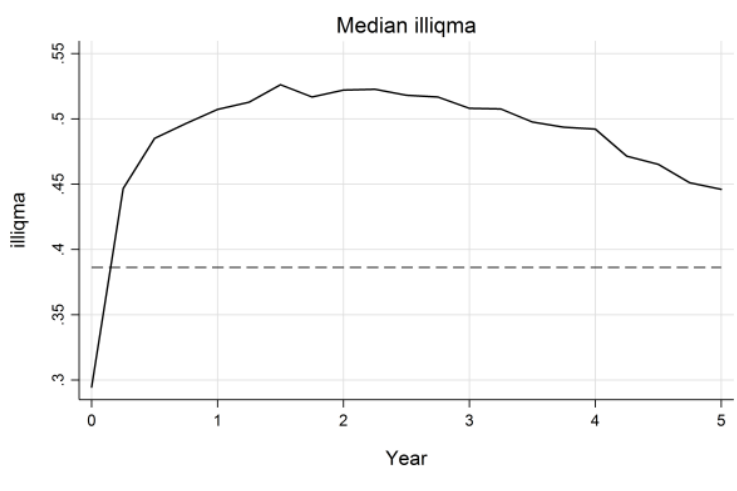

- IPO ----- Mature 


\section{Table A.1: Over which time horizon do IPOs underperform? - Firm size}

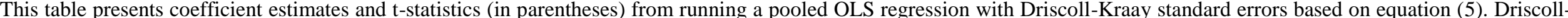

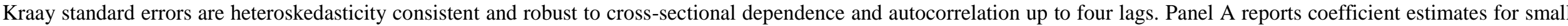

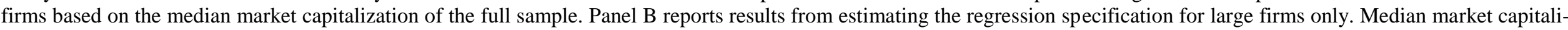

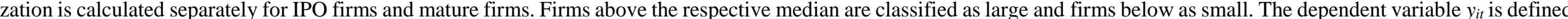

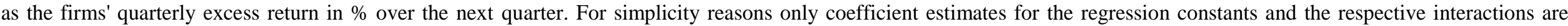

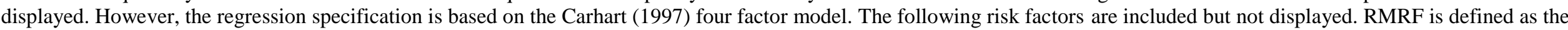

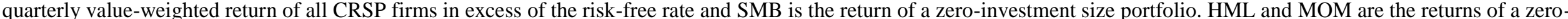

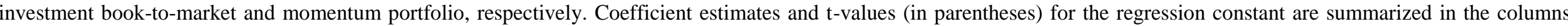

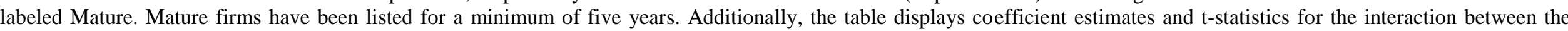

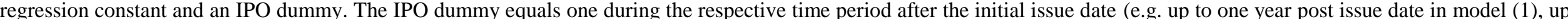

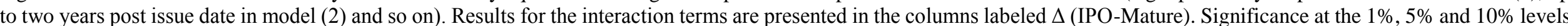
are indicated by $* * *, * *$ and $*$, respectively.

\begin{tabular}{|c|c|c|c|c|c|c|c|c|c|c|}
\hline Model & & & & & & & & & & \\
\hline \multirow[t]{2}{*}{ Time post IPO } & \multicolumn{2}{|c|}{ up to 1 year } & \multicolumn{2}{|c|}{ up to 2 years } & \multicolumn{2}{|c|}{ up to 3 years } & \multicolumn{2}{|c|}{ up to 4 years } & \multicolumn{2}{|c|}{ up to 5 years } \\
\hline & Mature & $\begin{array}{l}\Delta \text { (IPO-Ma- } \\
\text { ture })\end{array}$ & Mature & $\begin{array}{l}\Delta \text { (IPO-Ma- } \\
\text { ture })\end{array}$ & Mature & $\begin{array}{l}\Delta(\text { IPO-Ma- } \\
\text { ture })\end{array}$ & Mature & $\begin{array}{l}\Delta(\text { IPO-Ma- } \\
\text { ture })\end{array}$ & Mature & $\begin{array}{l}\Delta(\text { IPO- } \\
\text { Mature })\end{array}$ \\
\hline
\end{tabular}

Panel A: Small Firms

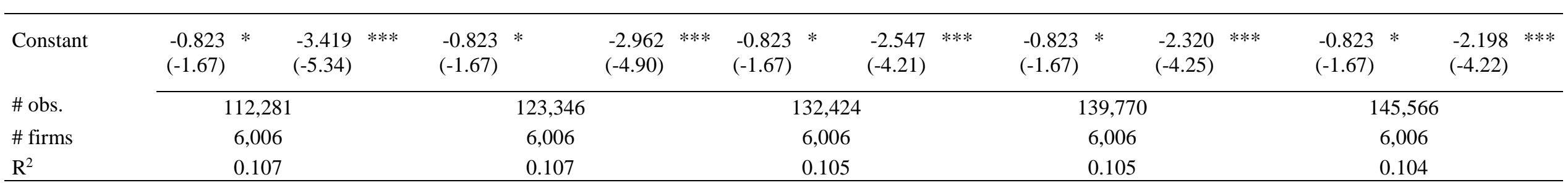

Panel B: Large Firms

\begin{tabular}{|c|c|c|c|c|c|c|c|c|c|c|c|c|c|c|c|}
\hline Constant & $\begin{array}{l}1.145 \\
(4.52)\end{array}$ & $* * *$ & $\begin{array}{l}-2.040 \\
(-1.42)\end{array}$ & $\begin{array}{l}1.145 \\
(4.52)\end{array}$ & $* * *$ & $\begin{array}{l}-1.144 \\
(-1.03)\end{array}$ & $\begin{array}{r}1.145 \\
(4.52)\end{array}$ & $* * *$ & $\begin{array}{l}-0.587 \\
(-0.61)\end{array}$ & $\begin{array}{r}1.145 \\
(4.52)\end{array}$ & & $\begin{array}{l}-0.382 \\
(-0.46)\end{array}$ & $\begin{array}{r}1.145 \\
(4.52)\end{array}$ & $* * *$ & $\begin{array}{l}-0.227 \\
(-0.34)\end{array}$ \\
\hline \# obs. & \multicolumn{3}{|c|}{238,007} & \multicolumn{3}{|c|}{248,456} & \multicolumn{3}{|c|}{257,525} & \multicolumn{3}{|c|}{265,301} & \multicolumn{3}{|c|}{272,048} \\
\hline \# firms & \multicolumn{3}{|c|}{5,644} & \multicolumn{3}{|c|}{5,644} & \multicolumn{3}{|c|}{5,644} & \multicolumn{3}{|c|}{5,644} & \multicolumn{3}{|c|}{5,644} \\
\hline $\mathrm{R}^{2}$ & \multicolumn{3}{|c|}{0.150} & \multicolumn{3}{|c|}{0.152} & \multicolumn{3}{|c|}{0.152} & \multicolumn{3}{|c|}{0.153} & \multicolumn{3}{|c|}{0.153} \\
\hline
\end{tabular}


Table A.2: Over which time horizon do IPOs underperform? - Sample period

This table presents coefficient estimates and t-statistics (in parentheses) from running a pooled OLS regression with Driscoll-Kraay standard errors based on equation (5). Driscoll-Kraay standard errors are heteroskedasticity consistent and robust to cross-sectional dependence and autocorrelation up to four lags. Panel A reports coefficient estimates over the time period 1975 to 2000 . Panel B reports results from estimating the regression specification over the time period 2001 to 2014 . The dependent variable $y_{i t}$ is defined as the firms' quarterly excess return in \% over the next quarter. For simplicity reasons only coefficient estimates for the regression constants and the respective interactions are displayed. However, the regression specification is based on the Carhart (1997) four factor model. The following risk factors are included but not displayed. RMRF is defined as the quarterly value-weighted return of all CRSP firms in excess of the risk-free rate and SMB is the return of a zero-investment size portfolio. HML and MOM are the returns of a zero-investment book-to-market and momentum portfolio, respectively. Coefficient estimates and t-values (in parentheses) for the regression constant are summarized in the columns labeled Mature. Mature firms have been listed for a minimum of five years. Additionally, the table displays coefficient estimates and t-statistics for the interaction between the regression constant and an IPO dummy. The IPO dummy equals one during the respective time period after the initial issue date (e.g. up to one year post issue date in model (1), up to two years post issue date in model (2) and so on). Results for the interaction terms are presented in the columns labeled $\Delta$ (IPO-Mature). Significance at the $1 \%, 5 \%$ and $10 \%$ levels are indicated by $* * *, * *$ and $*$, respectively.

\begin{tabular}{|c|c|c|c|c|c|}
\hline \multirow{3}{*}{$\begin{array}{l}\text { Model } \\
\text { Time } \\
\text { post IPO }\end{array}$} & (1) & (2) & (3) & (4) & (5) \\
\hline & up to 1 year & up to 2 years & up to 3 years & up to 4 years & up to 5 years \\
\hline & $\begin{array}{l}\Delta \text { (IPO-Ma- } \\
\text { ture) }\end{array}$ & $\begin{array}{c}\Delta(\text { IPO-Ma- } \\
\text { ture })\end{array}$ & $\begin{array}{l}\Delta \text { (IPO-Ma- } \\
\text { ture) }\end{array}$ & $\begin{array}{l}\Delta \text { (IPO-Ma- } \\
\text { ture) }\end{array}$ & $\begin{array}{l}\Delta \text { (IPO-Ma- } \\
\text { ture) }\end{array}$ \\
\hline
\end{tabular}

Panel A: 1975-2000

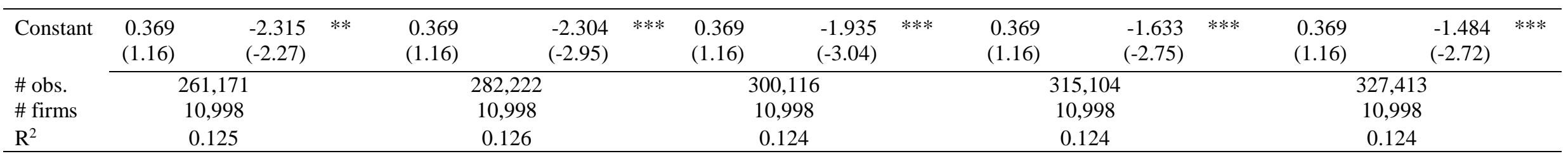

Panel B: 2001-2014

\begin{tabular}{|c|c|c|c|c|c|c|c|c|c|c|c|c|c|c|c|c|}
\hline Constant & $\begin{array}{r}1.010 \\
(2.29)\end{array}$ & $* *$ & $\begin{array}{l}-1.799 \\
(-1.99)\end{array}$ & $* *$ & $\begin{array}{l}1.010 \\
(2.29)\end{array}$ & $* *$ & $\begin{array}{c}-0.683 \\
(-0.87)\end{array}$ & $\begin{array}{r}1.010 \\
(2.29)\end{array}$ & $* *$ & $\begin{array}{l}0.047 \\
(0.06)\end{array}$ & $\begin{array}{r}1.010 \\
(2.29)\end{array}$ & $* *$ & $\begin{array}{c}0.204 \\
(0.27)\end{array}$ & $\begin{array}{l}1.010 \\
(2.29)\end{array}$ & $* *$ & $\begin{array}{r}0.300 \\
(0.45)\end{array}$ \\
\hline \# obs. & \multicolumn{3}{|c|}{133,796} & & \multicolumn{3}{|c|}{139,280} & \multicolumn{3}{|c|}{144,530} & \multicolumn{3}{|c|}{149,634} & \multicolumn{3}{|c|}{154,842} \\
\hline \# firms & \multicolumn{3}{|c|}{5,400} & & \multicolumn{3}{|c|}{5,400} & \multicolumn{3}{|c|}{5,400} & \multicolumn{3}{|c|}{5,400} & \multicolumn{3}{|c|}{5,400} \\
\hline $\mathrm{R}^{2}$ & \multicolumn{3}{|c|}{0.158} & & \multicolumn{3}{|c|}{0.164} & \multicolumn{3}{|c|}{0.167} & \multicolumn{3}{|c|}{0.168} & \multicolumn{3}{|c|}{0.167} \\
\hline
\end{tabular}




\section{Table A.3: Over which time horizon do IPOs underperform? - VC-backed vs. non-VC-backed IPOs}

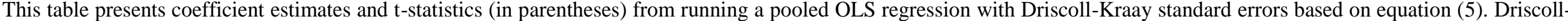

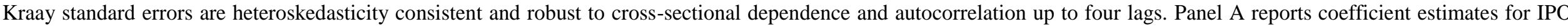

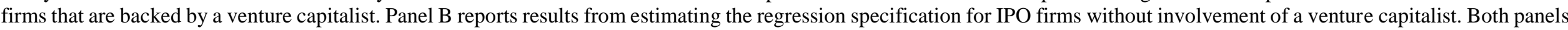

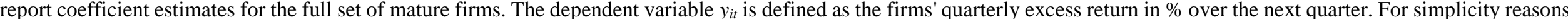

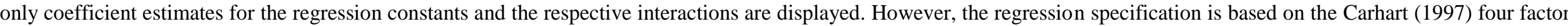

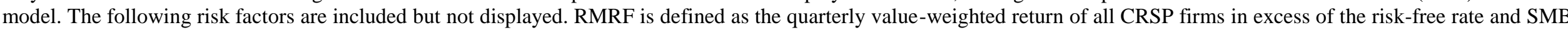

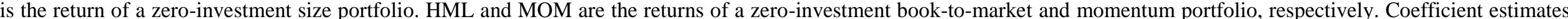

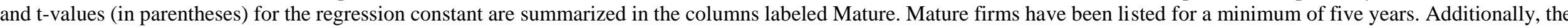

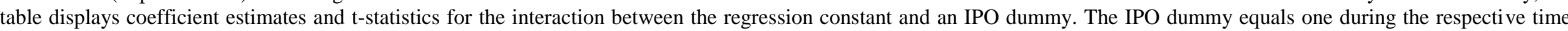

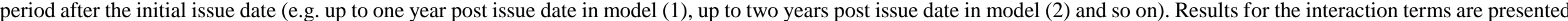
in the columns labeled $\Delta$ (IPO-Mature). Significance at the $1 \%, 5 \%$ and $10 \%$ levels are indicated by $* * *, * *$ and $*$, respectively.

\begin{tabular}{|c|c|c|c|c|c|}
\hline \multirow{3}{*}{$\begin{array}{l}\text { Model } \\
\text { Time } \\
\text { post IPO }\end{array}$} & (1) & (2) & (3) & (4) & $(5)$ \\
\hline & up to 1 year & up to 2 years & up to 3 years & up to 4 years & up to 5 years \\
\hline & $\begin{array}{c}\Delta \text { (IPO-Ma- } \\
\text { ture) }\end{array}$ & $\Delta$ (IPO-Mature) & $\begin{array}{c}\Delta \text { (IPO-Ma- } \\
\text { ture) }\end{array}$ & $\begin{array}{l}\Delta \text { (IPO-Ma- } \\
\text { ture })\end{array}$ & $\begin{array}{c}\Delta(\mathrm{IPO}-\mathrm{Ma}- \\
\text { ture })\end{array}$ \\
\hline
\end{tabular}

Panel A: Venture-backed IPOs

\begin{tabular}{|c|c|c|c|c|c|c|c|c|c|c|c|c|c|c|c|}
\hline Constant & $\begin{array}{c}0.746 \\
(2.50)\end{array}$ & $* *$ & $\begin{array}{l}-2.057 \\
(-1.53)\end{array}$ & $\begin{array}{l}0.746 \\
(2.50)\end{array}$ & $* *$ & $\begin{array}{l}-0.646 \\
(-0.55)\end{array}$ & $\begin{array}{l}0.746 \\
(2.50)\end{array}$ & & $\begin{array}{c}0.238 \\
(0.23)\end{array}$ & $\begin{array}{c}0.746 \\
(2.50)\end{array}$ & $* *$ & $\begin{array}{c}0.475 \\
(0.52)\end{array}$ & $\begin{array}{c}0.746 \\
(2.50)\end{array}$ & $* *$ & $\begin{array}{c}0.471 \\
(0.58)\end{array}$ \\
\hline \# obs. & \multicolumn{3}{|c|}{376,980} & \multicolumn{3}{|c|}{387,204} & \multicolumn{3}{|c|}{396,190} & \multicolumn{3}{|c|}{403,993} & \multicolumn{3}{|c|}{410,815} \\
\hline \# firms & \multicolumn{3}{|c|}{10,805} & \multicolumn{3}{|c|}{10,805} & \multicolumn{3}{|c|}{10,805} & \multicolumn{3}{|c|}{10,805} & \multicolumn{3}{|c|}{10,805} \\
\hline $\mathrm{R}^{2}$ & \multicolumn{3}{|c|}{0.135} & \multicolumn{3}{|c|}{0.138} & \multicolumn{3}{|c|}{0.140} & \multicolumn{3}{|c|}{0.141} & \multicolumn{3}{|c|}{0.142} \\
\hline
\end{tabular}

Panel B: Nonventure-backed IPOs

\begin{tabular}{|c|c|c|c|c|c|c|c|c|c|c|c|c|c|c|c|c|c|c|c|c|}
\hline Constant & $\begin{array}{l}0.746 \\
(2.50)\end{array}$ & $* *$ & $\begin{array}{l}-2.640 \\
(-4.39)\end{array}$ & $* * *$ & $\begin{array}{l}0.746 \\
(2.50)\end{array}$ & $* *$ & $\begin{array}{l}-2.492 \\
(-4.82)\end{array}$ & $* * *$ & $\begin{array}{l}0.746 \\
(2.50)\end{array}$ & $* *$ & $\begin{array}{l}-2.123 \\
(-4.52)\end{array}$ & $* * *$ & $\begin{array}{l}0.746 \\
(2.50)\end{array}$ & $* *$ & $\begin{array}{l}-1.892 \\
(-4.40)\end{array}$ & $* * *$ & $\begin{array}{l}0.746 \\
(2.50)\end{array}$ & $* *$ & $\begin{array}{l}-1.690 \\
(-4.21)\end{array}$ & $* * *$ \\
\hline \# obs. & \multicolumn{3}{|c|}{383,478} & & \multicolumn{3}{|c|}{399,724} & \multicolumn{5}{|c|}{413,829} & \multicolumn{3}{|c|}{426,077} & \multicolumn{5}{|c|}{436,744} \\
\hline \# firms & \multicolumn{3}{|c|}{11,537} & & \multicolumn{3}{|c|}{11,537} & \multicolumn{5}{|c|}{11,537} & \multicolumn{3}{|c|}{11,537} & \multicolumn{5}{|c|}{11,537} \\
\hline $\mathrm{R}^{2}$ & \multicolumn{3}{|c|}{0.130} & & \multicolumn{3}{|c|}{0.130} & \multicolumn{5}{|c|}{0.128} & \multicolumn{3}{|c|}{0.129} & \multicolumn{5}{|c|}{0.128} \\
\hline
\end{tabular}




\section{Table A.4: Over which time horizon do IPOs underperform? - IPO underpricing}

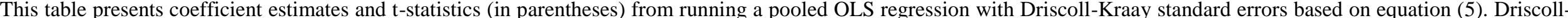

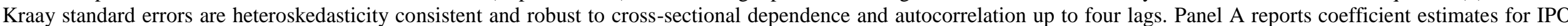

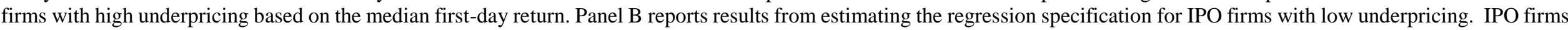

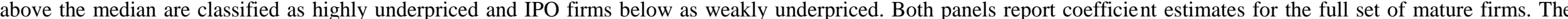

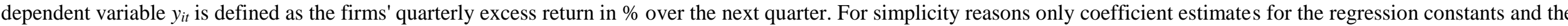

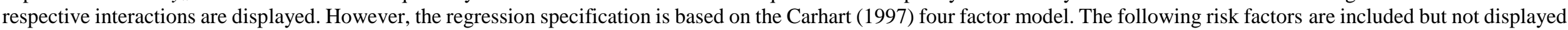

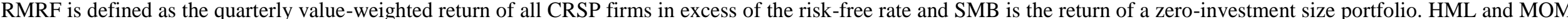

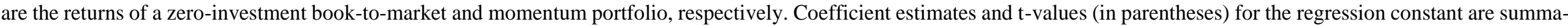

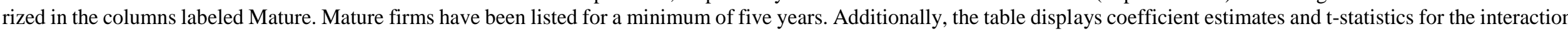

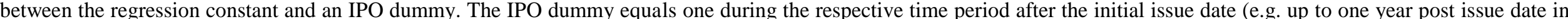

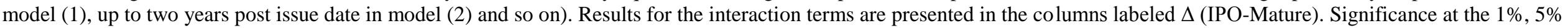
and $10 \%$ levels are indicated by $* * *, * *$ and $*$, respectively.

\begin{tabular}{|c|c|c|c|c|c|c|c|c|c|c|}
\hline \multirow{3}{*}{$\begin{array}{l}\text { Model } \\
\text { Time } \\
\text { post IPO }\end{array}$} & \multicolumn{2}{|c|}{ (1) } & \multicolumn{2}{|c|}{ (2) } & \multicolumn{2}{|c|}{ (3) } & \multicolumn{2}{|c|}{ (4) } & \multicolumn{2}{|c|}{ (5) } \\
\hline & & year & & 2 years & & years & & years & & years \\
\hline & Mature & $\begin{array}{c}\Delta \text { (IPO-Ma- } \\
\text { ture })\end{array}$ & Mature & $\Delta$ (IPO-Mature) & Mature & $\begin{array}{c}\Delta \text { (IPO-Ma- } \\
\text { ture })\end{array}$ & Mature & $\begin{array}{c}\Delta \text { (IPO-Ma- } \\
\text { ture })\end{array}$ & Mature & $\begin{array}{l}\Delta \text { (IPO-Ma- } \\
\text { ture })\end{array}$ \\
\hline
\end{tabular}

Panel A: High Underpricing

\begin{tabular}{|c|c|c|c|c|c|c|c|c|c|c|c|c|c|c|c|c|}
\hline Constant & $\begin{array}{c}0.746 \\
(2.50)\end{array}$ & $* *$ & $\begin{array}{l}-2.540 \\
(-2.08)\end{array}$ & $* *$ & $\begin{array}{l}0.746 \\
(2.50)\end{array}$ & $* *$ & $\begin{array}{l}-1.515 \\
(-1.30)\end{array}$ & $\begin{array}{c}0.746 \\
(2.50)\end{array}$ & $* *$ & $\begin{array}{r}-0.724 \\
(-0.65)\end{array}$ & $\begin{array}{l}0.746 \\
(2.50)\end{array}$ & $* *$ & $\begin{array}{l}-0.556 \\
(-0.59)\end{array}$ & $\begin{array}{l}0.746 \\
(2.50)\end{array}$ & $* *$ & $\begin{array}{l}-0.433 \\
(-0.51)\end{array}$ \\
\hline \# obs. & \multicolumn{3}{|c|}{379,840} & & \multicolumn{3}{|c|}{392,764} & \multicolumn{3}{|c|}{403,986} & \multicolumn{3}{|c|}{413,640} & \multicolumn{3}{|c|}{422,050} \\
\hline \# firms & \multicolumn{4}{|c|}{11,134} & \multicolumn{3}{|c|}{11,134} & \multicolumn{3}{|c|}{11,134} & \multicolumn{3}{|c|}{11,134} & \\
\hline $\mathrm{R}^{2}$ & \multicolumn{3}{|c|}{0.134} & & \multicolumn{3}{|c|}{0.137} & \multicolumn{3}{|c|}{0.137} & \multicolumn{3}{|c|}{0.137} & \multicolumn{3}{|c|}{$\begin{array}{c}11,134 \\
0136\end{array}$} \\
\hline
\end{tabular}

Panel B: Low Underpricing

\begin{tabular}{|c|c|c|c|c|c|c|c|c|c|c|c|c|c|c|c|c|c|c|c|c|}
\hline Constant & $\begin{array}{c}0.746 \\
(2.50)\end{array}$ & $* *$ & $\begin{array}{l}-2.189 \\
(-3.90)\end{array}$ & $* * *$ & $\begin{array}{l}0.746 \\
(2.50)\end{array}$ & $* *$ & $\begin{array}{l}-1.909 \\
(-4.56)\end{array}$ & $* * *$ & $\begin{array}{l}0.746 \\
(2.50)\end{array}$ & $* *$ & $\begin{array}{l}-1.480 \\
(-3.58)\end{array}$ & $* * *$ & $\begin{array}{l}0.746 \\
(2.50)\end{array}$ & $* *$ & $\begin{array}{l}-1.204 \\
(-3.07)\end{array}$ & $* * *$ & $\begin{array}{l}0.746 \\
(2.50)\end{array}$ & $* *$ & $\begin{array}{l}-1.130 \\
(-2.97)\end{array}$ & $* * *$ \\
\hline \# obs. & \multicolumn{3}{|c|}{380,689} & & \multicolumn{3}{|c|}{394,296} & \multicolumn{5}{|c|}{406,214} & \multicolumn{3}{|c|}{416,648} & \multicolumn{5}{|c|}{425,751} \\
\hline \# firms & \multicolumn{4}{|c|}{11,222} & \multicolumn{3}{|c|}{11,222} & \multicolumn{5}{|c|}{11,222} & \multicolumn{3}{|c|}{11,222} & \multicolumn{5}{|c|}{11,222} \\
\hline $\mathrm{R}^{2}$ & \multicolumn{3}{|c|}{0.131} & & \multicolumn{3}{|c|}{0.131} & \multicolumn{5}{|c|}{0.130} & \multicolumn{3}{|c|}{0.131} & \multicolumn{5}{|c|}{0.131} \\
\hline
\end{tabular}


Figure A.1: The number of U.S. IPOs per year

This figure presents the annual number of firms going public in the United States from 1975 to 2014.

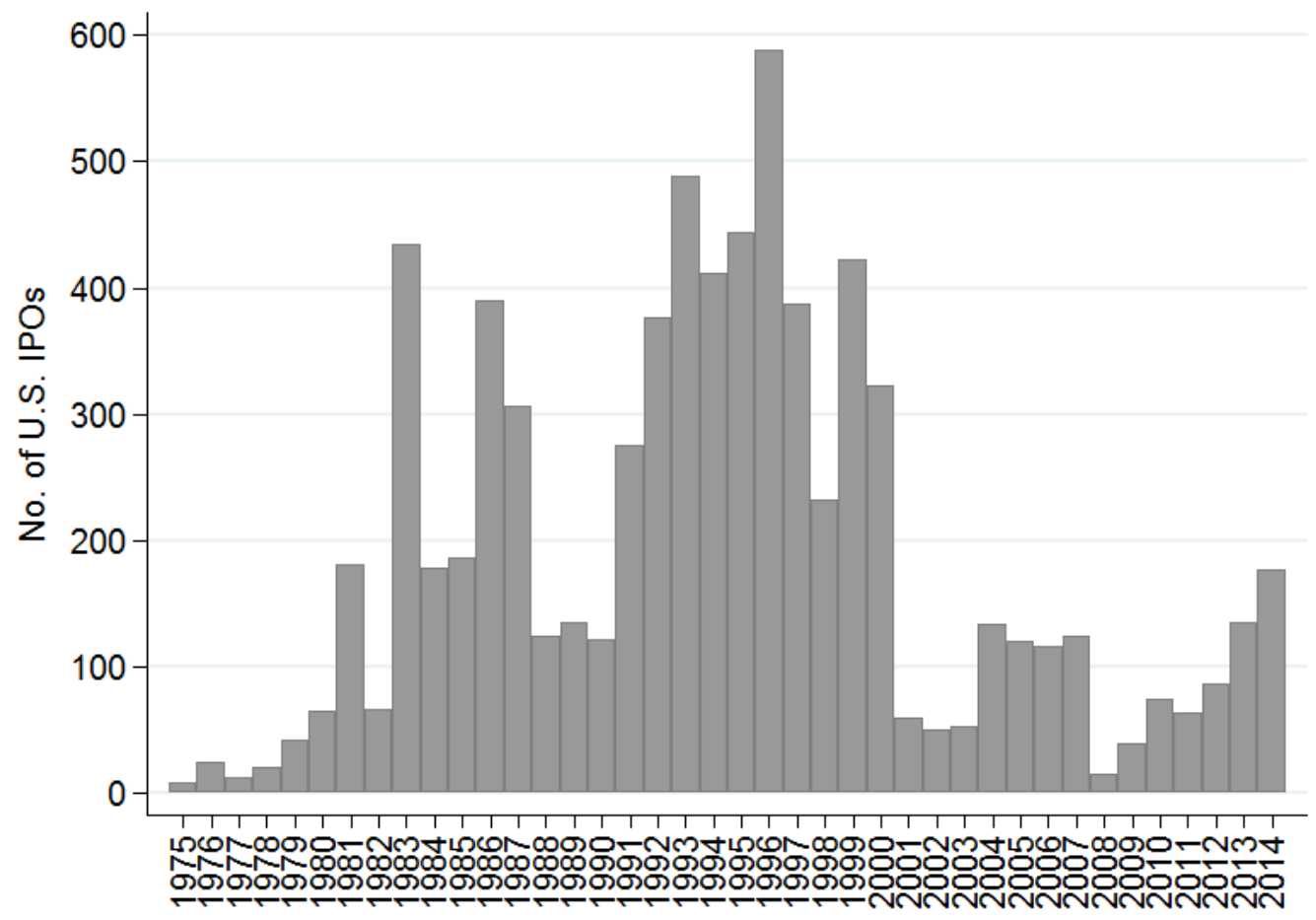

